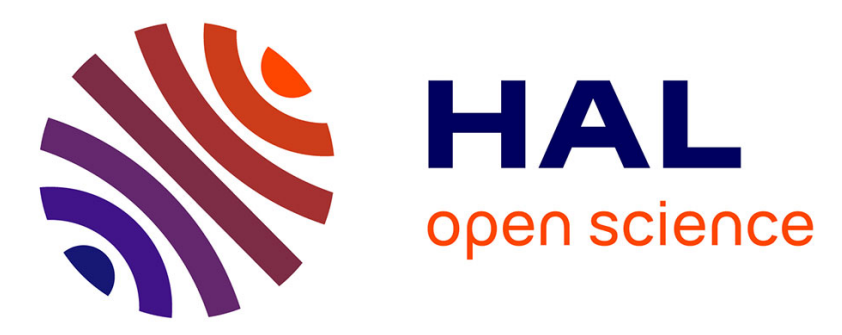

\title{
Degradation of ibuprofen and phenol with a Fenton-like process triggered by zero-valent iron (ZVI-Fenton)
}

Marco Minella, Stefano Bertinetti, Khalil Hanna, Claudio Minero, Davide

Vione

\section{- To cite this version:}

Marco Minella, Stefano Bertinetti, Khalil Hanna, Claudio Minero, Davide Vione. Degradation of ibuprofen and phenol with a Fenton-like process triggered by zero-valent iron (ZVI-Fenton). Environmental Research, 2019, 179 (Pt A), pp.108750. 10.1016/j.envres.2019.108750 . hal-02307030

\section{HAL Id: hal-02307030 \\ https://hal-univ-rennes1.archives-ouvertes.fr/hal-02307030}

Submitted on 26 May 2020

HAL is a multi-disciplinary open access archive for the deposit and dissemination of scientific research documents, whether they are published or not. The documents may come from teaching and research institutions in France or abroad, or from public or private research centers.
L'archive ouverte pluridisciplinaire HAL, est destinée au dépôt et à la diffusion de documents scientifiques de niveau recherche, publiés ou non, émanant des établissements d'enseignement et de recherche français ou étrangers, des laboratoires publics ou privés. 


\section{Degradation of ibuprofen and phenol with a Fenton-}

\section{like process triggered by zero-valent iron (ZVI-Fenton)}

Marco Minella, ${ }^{a}$ Stefano Bertinetti, ${ }^{\text {a }}$ Khalil Hanna, ${ }^{\mathrm{b}}$ Claudio Minero, ${ }^{\mathrm{a}}$ Davide Vione $*^{\mathrm{a}}$

a Dipartimento di Chimica, Università di Torino, Via Pietro Giuria 5, 10125 Torino, Italy

${ }^{\mathrm{b}}$ Univ Rennes, Ecole Nationale Supérieure de Chimie de Rennes, CNRS, ISCR - UMR6226, F-35000 Rennes, France.

* Correspondence. Tel: +39-011-6705296; Fax +39-011-6705242. E-mail: davide.vione@ unito.it

ORCID:

Marco Minella: 0000-0003-0152-460X

Khalil Hanna: 0000-0002-6072-1294

Claudio Minero: 0000-0001-9484-130X

Davide Vione: 0000-0002-2841-5721 


\section{Abstract}

It is shown here that ZVI-Fenton is a suitable technique to achieve effective degradation of ibuprofen and phenol under several operational conditions. Degradation of ibuprofen was possible in the pH interval 3-6 in both synthetic laboratory systems and actual wastewater (secondary treatment effluent), but operation at the higher $\mathrm{pH}$ values required higher $\mathrm{H}_{2} \mathrm{O}_{2}$ concentration and/or higher ZVI loading. In the case of real wastewater we offset the lower degradation efficiency, caused by the occurrence of organic and inorganic interfering agents, by carrying out multiple $\mathrm{H}_{2} \mathrm{O}_{2}$ additions. The studied wastewater sample had a buffercapacity minimum at $\mathrm{pH} 4-5$, and optimal treatment for ibuprofen degradation might take place at either $\mathrm{pH} 4$ or 6 . With a reagents cost in the order of $0.06-0.10 \$ \mathrm{~m}^{-3}$, the technique appears as very competitive and promising for tertiary wastewater treatment. There is a clear trade-off between savings in $\mathrm{pH}$-fixing reagents and higher consumption of ZVI-Fenton reagents at the different $\mathrm{pH}$ values. The final choice in real application scenarios could be based on cost considerations (which favour $\mathrm{pH} 4$ ) and/or the eventual fate of wastewater. For instance, wastewater reuse might place requirements on the salinity that is increased by the acidification/neutralization steps: in this case, operation at $\mathrm{pH} 6$ is preferred. Interestingly, the ZVI-Fenton degradation of ibuprofen led to very low generation of toxic 4isobutylacetophenone (IBAP, which is the ibuprofen by-product raising the highest concern), because of the combination of low formation yields and limited IBAP stability in the optimal reaction conditions. In addition to ibuprofen, phenol could be degraded as well by ZVI-Fenton. Interestingly, the ability of ZVIFenton to degrade both ibuprofen and phenol under similar conditions might open up the way to apply this technique to additional pollutants as well as to pollutant mixtures.

Keywords: Zero-valent iron; Fenton reaction; Pharmaceuticals and personal care products; Tertiary water treatment; Advanced oxidation processes.

\section{Funding Resources}

This work was financially supported by University of Torino (Ricerca Locale) and Compagnia di San Paolo (project CSTO168282-ABATEPHARM). The same source provided funding for Stefano Bertinetti's bursary. 


\section{Introduction}

The consumption of pharmaceuticals is increasing worldwide because of different factors such as population growth, development of pharmaceutical industry and of medical sciences (Le Corre et al. 2012), and economic growth of developing countries. For instance, the worldwide consumption of antibiotics has increased by 35\% between 2000 and 2010 (Van Boeckel et al. 2014). Pharmaceuticals consumption has greatly improved life expectancy and quality (Frech and Miller 2004), but it has also increased the release of these chemicals into the environment and especially surface waters. Pharmaceuticals can enter the water cycle either via the pharmaceutical industry wastewater or through (even treated) urban wastewater, because these compounds are contained in faeces and especially urine and may also derive from "down the drain" incorrect disposal of unused or outdated medicines (Richardson and Bowron 1985; Mirzaei et al. 2017; Saeid et al 2018). Many pharmaceuticals are recalcitrant to traditional water treatment, and they are frequently detected at the wastewater treatment plant (WWTP) outlet (Richardson and Ternes 2014). Further sources of pharmaceuticals to the environment are also veterinary clinics, livestock husbandry and aquaculture activities (Richardson and Bowron 1985; Mirzaei et al. 2017; Saeid et al 2018). Once they reach surface waters, pharmaceuticals can cause toxic and related effects to aquatic organisms (some of these compounds are for instance well-known endocrine disruptors; Rubasinghege et al. 2018) as well as more subtle phenomena, such as the insurgence of antibiotic resistance in bacteria (Huijbers et al. 2015). Moreover, the environmental transformation of the parent drugs may sometimes generate harmful by-products (Rubasinghege et al. 2018; Wang and Lin 2012; Ruggeri et al. 2013). These problems are further exacerbated by the ever-growing need to re-use treated wastewater for industrial and agricultural activities and, in some cases of chronic water scarcity, to obtain drinking water as well (Le-Minh et al. 2010). Because of the limited effectiveness of primary and secondary water treatment towards pharmaceuticals, tertiary and advanced treatments are required to safely remove these compounds (Le-Minh et al. 2010; Homem and Santos 2011; Méndez-Arriaga et al. 2010).

Ibuprofen is one of the most common non-steroidal, anti-inflammatory drugs (NSAIDs). It is almost always detected at the WWTP inlet (Zorita et al. 2009), especially during the winter months due to its use as antipyretic (Vione et al. 2011). Because of incomplete WWTP removal, ibuprofen is also frequently found at the WWTP outlet (Pasquini et al. 2014; Stasinakis et al. 2012) as well as in downstream river water, where it can occur at levels of up to tens or hundreds

$\mu \mathrm{g} \mathrm{L}^{-1}$ (Zorita et al. 2009; Pasquini et al. 2014; Stasinakis et al. 2012). Ibuprofen shows 
accumulation potential in aquatic organisms (Zhang et al. 2010), and it has detrimental effects over the freshwater biota (De Lange et al. 2009). Moreover, the transformation of ibuprofen in freshwater can produce 4-isobutylacetophenone (IBAP), which can also be found in outdated ibuprofen formulations and is considerably more toxic than the parent compound (Ruggeri et al. 2013). Therefore, it is important to find methods to effectively remove ibuprofen from wastewater.

Among the possible tertiary treatment options, adsorption on activated carbon or other highcapacity materials can effectively remove pharmaceuticals from wastewater, but in this case the problem is shifted from water to a solid phase (e.g., exhausted carbon) that requires further treatment (Mirzaei et al. 2017). The direct degradation of pollutants in the water phase may be a more straightforward option. Oxidative processes such as chlorination, ozonation and UV irradiation are widely used in wastewater treatment plants, but they are not always able to achieve effective degradation of recalcitrant contaminants (Le-Minh et al. 2010; Homem and Santos 2011). Such a goal can often be reached by using the so-called advanced oxidation processes (AOPs), which are a set of techniques based on the formation of strongly reactive transient species such as the hydroxyl radical, ${ }^{\circ} \mathrm{OH}\left(\mathrm{E}^{\mathrm{O}} \cdot \mathrm{OH} / \mathrm{OH}-=1.90 \mathrm{~V}\right.$ and $\left.\mathrm{E}^{\mathrm{o}} \cdot \mathrm{OH}, \mathrm{H}+\mathrm{H} 2 \mathrm{O}=2.73 \mathrm{~V}\right)$ (Comninellis et al. 2008; Gligorovski et al. 2015). Among the different AOPs, the Fenton reaction is interesting because of ease of operation, cost effectiveness (Fang et al. 2018), and environmentally benign nature of its reagents (Mirzaei et al. 2017). In fact, the Fenton chemistry is based upon the reaction between $\mathrm{Fe}^{2+}$ ions and $\mathrm{H}_{2} \mathrm{O}_{2}$ to produce ${ }^{\circ} \mathrm{OH}$ (reaction 1). The actual formation of ${ }^{\circ} \mathrm{OH}$ vs. additional oxidants such as ferryl $\left(\mathrm{FeO}^{2+}\right)$ is still a matter of controversy (Gligorovski et al. 2015), and here " ${ }^{\circ} \mathrm{OH} "$ represents all the oxidizing, reactive species formed in the Fenton process. Residual $\mathrm{H}_{2} \mathrm{O}_{2}$ may be problematic if the Fenton treatment is followed by an activated sludge step (Watts et al. 2003). In the framework of tertiary water treatment, however, the anti-bacterial action of $\mathrm{H}_{2} \mathrm{O}_{2}$ may be even an advantage, because wastewater disinfection is needed before eventual discharge.

$$
\mathrm{Fe}^{2+}+\mathrm{H}_{2} \mathrm{O}_{2} \rightarrow \mathrm{Fe}(\mathrm{III})+\mathrm{OH}^{-}+{ }^{\circ} \mathrm{OH}
$$

The optimal $\mathrm{pH}$ value of the Fenton reaction is usually around 3 (Pignatello et al. 2006; Minella et al. 2014), which raises the need of neutralizing the treated solutions. The neutralization step causes $\mathrm{Fe}(\mathrm{III})$ precipitation, which on the one hand helps meeting the requirements of dissolved Fe concentration for wastewater discharge (around 1-2 $\mathrm{mg}_{\mathrm{Fe}} \mathrm{L}^{-1}$ in several countries) (Zhong et al. 2012), but on the other hand produces a sludge that has to be dealt with. A possible way to 
minimize sludge production is to keep the $\left[\mathrm{Fe}^{2+}\right] /\left[\mathrm{H}_{2} \mathrm{O}_{2}\right]$ ratio low, in which case the following reactions are exploited to regenerate $\mathrm{Fe}^{2+}$ (Zhong et al. 2012; Pignatello et al. 2006; Minella et al. 2014):

$$
\begin{aligned}
& \mathrm{Fe}(\mathrm{III})+\mathrm{H}_{2} \mathrm{O}_{2} \rightarrow \mathrm{Fe}^{2+}+\mathrm{H}^{+}+\mathrm{HO}_{2} \\
& \mathrm{Fe}(\mathrm{III})+\mathrm{O}_{2}^{--} \rightarrow \mathrm{Fe}^{2+}+\mathrm{O}_{2}
\end{aligned}
$$

The adjustment of $\left[\mathrm{Fe}^{2+}\right]$ and $\left[\mathrm{H}_{2} \mathrm{O}_{2}\right]$ is also aimed at minimizing ${ }^{\circ} \mathrm{OH}$ scavenging by both species (Neyens and Baeyens 2003). However, this approach suffers from at least two important drawbacks: $(i)$ the cost of the pH-fixing reagents is at least as high as that of $\mathrm{H}_{2} \mathrm{O}_{2}$, and together they make up $\sim 80 \%$ of the expense for chemicals in the Fenton process (Minella et al. 2018); (ii) when treating actual wastewater, the recycling of Fe(III) via reactions $(2,3)$ is too slow to be effectively exploited in a real-world scenario (Minella et al. 2018). An alternative way to tackle the problem is represented by heterogeneous Fenton, where the Fe source is a solid material (better if magnetic, which makes subsequent separation easier) (Pastrana-Martínez et al. 2015; Tang and Lo 2013).

Among the Fe-containing magnetic materials that can be used in heterogeneous Fenton, magnetite $\left(\mathrm{Fe}_{3} \mathrm{O}_{4}\right)$ is potentially effective because of the $\mathrm{Fe}^{2+}$ ions contained in its lattice structure. However, $\mathrm{Fe}_{3} \mathrm{O}_{4}$ quickly loses efficiency because of the fast oxidation of surface $\mathrm{Fe}(\mathrm{II})$ to much less active Fe(III) (Minella et al. 2014; Avetta et al. 2015; Bertinetti et al. 2019). In contrast, metallic Fe (or zero-valent iron, ZVI) is Fenton-active and, although easily oxidized, it gets covered by a Fe(II) layer that takes part in the Fenton process as well (Litter and Slodowicz 2017; Rezaei and Vione 2018). Indeed, the Fenton reactivity of ZVI undergoes limited influence by weathering, corrosion and surface passivation (Minella et al. 2016). ZVI is better known as a reducing agent that can be used in the reductive (not oxidative) treatment of pollutants occurring in, e.g., groundwater, such as for instance chlorinated compounds, nitroaromatics, $\mathrm{CrO}_{4}{ }^{2-}, \mathrm{As}(\mathrm{III}), \mathrm{As}(\mathrm{V}), \mathrm{NO}_{3}{ }^{-}, \mathrm{U}(\mathrm{VI})(\mathrm{Fu}$ et al. 2014). However, in the presence of $\mathrm{O}_{2}$ or especially $\mathrm{H}_{2} \mathrm{O}_{2}, \mathrm{ZVI}$ is able to take part to the Fenton reaction (Fu et al. 2014; Ling et al. 2018). In heterogeneous Fenton processes the reaction between $\mathrm{Fe}(\mathrm{II})$ and $\mathrm{H}_{2} \mathrm{O}_{2}$ may either take place in solution, with $\mathrm{Fe}^{2+}$ leached from the solid surface, or involve surface $\mathrm{Fe}(\mathrm{II})$ and dissolved $\mathrm{H}_{2} \mathrm{O}_{2}$ (Minella et al. 2016; Nidheesh 2015). In the case of ZVI, Fe(II) leaching is too limited to account for the observed reaction and the solid surface plays a major role (Minella et al. 2016; Ling et al. 2018). Although most efficient at pH 3 , the ZVI-Fenton reaction is also effective at higher $\mathrm{pH}$ values (Minella et al. 2016), thus it might help tackle the main problems encountered with the traditional Fenton process. 
Although ZVI-Fenton has been used to degrade organic contaminants (Litter and Slodowicz 2017), very little knowledge exists into its ability to remove ibuprofen under environmentally relevant conditions, and nothing into the possible formation of toxic IBAP. In addition, the use of ZVI as iron source to promote the Fenton oxidation has been scarcely investigated in real wastewaters. In this matrix, the degradation efficiency may be lower than in laboratory systems due to the interference by organic matter and inorganic ions (Minella et al. 2018). Finally, to our knowledge the economics of the process in real wastewater has been scarcely taken into account, which is a problem because economic considerations are of paramount importance in water treatment. Ibuprofen was here selected as model emerging contaminant, because it is a major pharmaceutical frequently found in wastewater and surface waters, and because of the known occurrence of a toxic by-product (IBAP) formed by oxidative processes. This issue allows for the assessment of the degradation efficiency of ZVI-Fenton towards both the target compound and an intermediate of concern. We also checked for the ability of ZVI-Fenton to degrade phenol, because $(i)$ phenol has been widely used in several AOP degradation studies (Minella et al. 2014; Avetta et al. 2015; Minella et al. 2016; Bertinetti et al. 2019), thereby allowing for a straightforward comparison of performance, and (ii) it is an actual pollutant emitted by pharmaceutical and petrochemical industries (Busca et al. 2008).

\section{Experimental section}

\subsection{Reagents and materials}

Phenol (purity grade 99\%), ibuprofen $(\geq 98 \%), \mathrm{HClO}_{4}(70 \% \mathrm{w} / \mathrm{w}), \mathrm{NaOH}(\geq 90 \%)$, methanol (gradient grade), $\mathrm{H}_{2} \mathrm{SO}_{4}\left(96 \%\right.$ w/w), $\mathrm{H}_{3} \mathrm{PO}_{4}\left(85 \%\right.$ w/w), $\mathrm{FeCl}_{3} \cdot 6 \mathrm{H}_{2} \mathrm{O}(99 \%), \mathrm{NaBH}_{4}(98 \%)$, ampyrone (4amino-2,3-dimethyl-1-phenyl-3-pyrazol-5-one; reagent grade), $\mathrm{NaH}_{2} \mathrm{PO}_{4}$ ( $\geq 99.9 \%$ ) and horseradish peroxidase were purchased from Sigma-Aldrich, $\mathrm{KSCN}(\geq 98 \%)$ and $\mathrm{FeSO}_{4} \cdot 7 \mathrm{H}_{2} \mathrm{O}(99.5 \%)$ from Merck, $\mathrm{Na}_{2} \mathrm{HPO}_{4}(\geq 98 \%)$ and 1,10-phenanthroline (>99\%) from Aldrich, $\mathrm{H}_{2} \mathrm{O}_{2}(30 \%$ w/v) from Applichem PanReac. These reagents were used as received, without further purification. The water used was of Milli-Q quality.

The real wastewater samples used in this work were obtained from the outflow of a secondary clarifier tank of an urban Waste Water Treatment Plant. They were used after rough pre-filtration with grade 1 qualitative filter paper (Whatman), to remove large suspended solids. The studied wastewater had $2 \mathrm{mg}_{\mathrm{C}} \mathrm{L}^{-1}$ dissolved organic carbon, initial $\mathrm{pH}=7.6$ and $0.14 \mu \mathrm{S} \mathrm{cm}^{-1}$ conductivity. Further parameters and details are reported elsewhere (Minella et al. 2018). 
A wastewater aliquot (50 mL initial volume) was titrated with a $9.95 \mathrm{mM}$ standard $\mathrm{HCl}$ solution, using a potentiometric titrator (Metrohm 702 SM Titrino) equipped with a Metrohm combined $\mathrm{pH}$ glass electrode (code number 6.0233.100), and controlled by the Metrohm software "Tiamo" (titration and more).

\subsection{Synthesis and characterization of ZVI nanoparticles}

To prepare $\mathrm{Fe}^{\mathrm{o}}$ nanoparticles, $10.0 \mathrm{~g}$ of $\mathrm{FeSO}_{4} \times 7 \mathrm{H}_{2} \mathrm{O}$ were dissolved in $100 \mathrm{~mL}$ methanol/water solution $(30 / 70, \% \mathrm{v} / \mathrm{v})$, previously flushed with nitrogen to expel dissolved oxygen. The solution pH was adjusted to 6.5-7.0 with 3.8 M NaOH, added drop-wise at a rate of $0.03 \mathrm{~mL} \mathrm{~s}^{-1}$. Then, 3.0 $\mathrm{g}$ of $\mathrm{NaBH}_{4}$ powder was added incrementally to the mixture for 30-35 minutes. After addition of all $\mathrm{NaBH}_{4}$ the mixture was stirred for 20 minutes, it was filtered through a $0.2 \mu \mathrm{m}$ pore-size filter and washed three times with absolute ethanol. The obtained solids were vacuum-dried at room temperature for 24 hours, and then grinded to obtain a powder. X-ray powder diffraction (XRD) experiments were performed to confirm the nature of the ZVI precipitate, and the X-ray diffractogram (not shown) was found to be identical to that of the expected solid. The particles were then characterized by scanning electron microscopy (SEM) (JEOL JSM 7100 F) and transmission electron microscopy (TEM) (JEOL JSM 6400). The BET surface area (40 $\pm 2 \mathrm{~m}^{2} \mathrm{~g}^{-1}$ ) was determined by nitrogen adsorption (multi-point $\mathrm{N}_{2}$ adsorption method; Autosorb, Quantachrome Instruments). The elemental composition and the composition of the outermost surface of particles were also analyzed by, respectively, Energy-dispersive X-ray spectroscopy (EDS) and X-ray photoelectron spectroscopy (XPS, ULVAC-PHI, model VersaProbe II).

According to SEM and TEM images, our ZVI particles were round-shaped and aggregated in form of chains (Fig. 1), which has been attributed to magnetic interactions between adjacent metallic particles (Lowry and Johnson 2004; Kanel et al. 2006), as well as to their natural tendency to remain in the most thermodynamically stable state (Cushing et al. 2004). TEM images also showed that the ZVI nanoparticles ranged in size from 20 to $50 \mathrm{~nm}$, and a thin passivation layer of iron oxide (3-4 nm) was present on the surface. According to the elemental composition (Table 1), and to the composition of the outermost surface of particles analysed by EDS and XPS (Table 2), ZVI particles have an external layer enriched with oxygen. The XPS data also indicate the presence of boron, sulphur and sodium impurities on the surface of the particles, left from the synthesis process. 
Table 1. Elemental composition of ZVI by EDS. Joumal Pre-proof

\begin{tabular}{lllll}
\hline$\% \mathrm{Fe}$ & $\% \mathrm{O}$ & $\% \mathrm{C}$ & $\% \mathrm{Na}$ & $\% \mathrm{~K}$ \\
\hline 66.7 & 20.1 & 2.6 & 8.1 & - \\
\hline
\end{tabular}

Table 2. Surface composition of ZVI by XPS.

\begin{tabular}{llllllll}
\hline$\% \mathrm{Fe}$ & $\% \mathrm{O}$ & $\% \mathrm{C}$ & $\% \mathrm{Na}$ & $\% \mathrm{~B}$ & $\% \mathrm{~S}$ & $\% \mathrm{Cl}$ & $\% \mathrm{~K}$ \\
\hline 41.0 & 40.2 & 1.9 & 9.5 & 5.3 & 2.1 & - & - \\
\hline
\end{tabular}

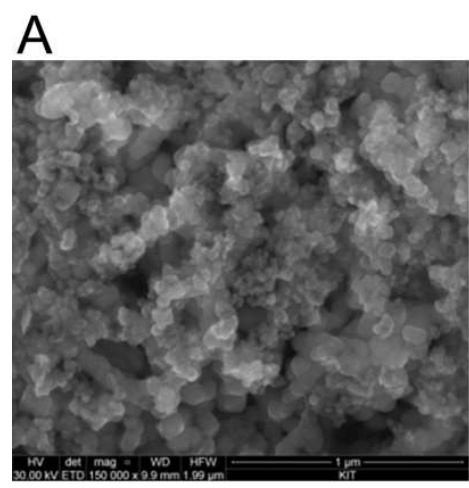

B

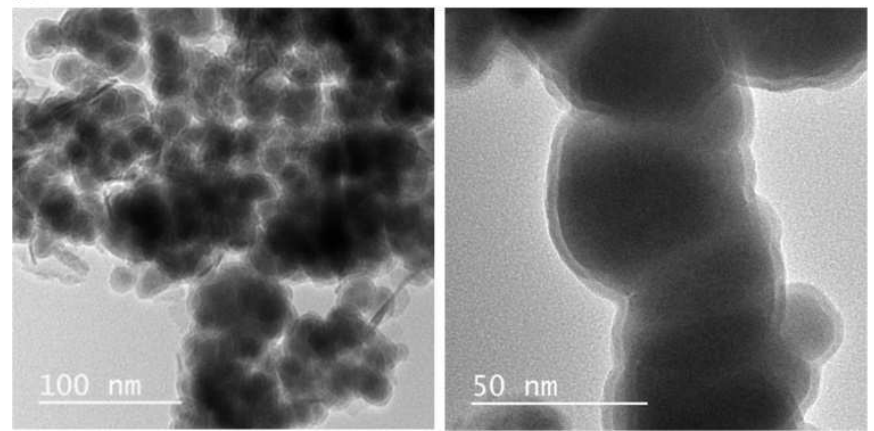

Fig. 1 (A) Scanning electron microscopy, and (B) Transmission electron microscopy images of synthesized ZVI.

\subsection{Phenol and ibuprofen degradation experiments}

Degradation experiments were carried out in beakers (the total volume of the aqueous phase was $300 \mathrm{~mL}$ ). The reaction mixture contained ZVI (heterogeneous catalyst), $\mathrm{H}_{2} \mathrm{O}_{2}$, the substrate (phenol or ibuprofen) and a reagent for $\mathrm{pH}$ adjustment $\left(\mathrm{HClO}_{4}\right.$ up to $\mathrm{pH} 4,10 \mathrm{mM}$ phosphate buffer for $\mathrm{pH} 5$ and above, $\mathrm{H}_{2} \mathrm{SO}_{4}$ for the wastewater experiments). In analogy with other studies (Méndez-Arriaga et al. 2010; Minella et al. 2018) the substrate concentration was kept as low as possible $(5 \mu \mathrm{M})$, compatibly with the need to reliably monitor the relevant time evolution by liquid chromatography. Indeed, pharmaceuticals are typically found at trace levels in wastewater, and we also wanted to minimize changes in suspension $\mathrm{pH}$ caused by the occurrence of degradation intermediates with acid-base properties. Unless otherwise specified, typical 
loading/concentration values for the ZVI-Fenton reagents in the reaction mixture were $0.01 \mathrm{~g} \mathrm{~L}^{-1}$ for ZVI and $50 \mu \mathrm{M}$ for $\mathrm{H}_{2} \mathrm{O}_{2}$.

At scheduled time intervals, a measured $3 \mathrm{~mL}$ sample aliquot was withdrawn from the reaction mixture and diluted 1:1 with the same volume of methanol to stop the Fenton reaction (Minella et al. 2016; Li and Goel 2010). ZVI was then removed from the sample by filtration on Millipore Millex $\mathrm{HV}$ filters (0.45 $\mu \mathrm{m}$ pore diameter). Phenol and ibuprofen were quantified by high performance liquid chromatography (HPLC), using a VWR-Hitachi Elite LaChrom instrument equipped with L2455 diode array detector (DAD), L2130 quaternary pump module, L2300 column oven (set at $40{ }^{\circ} \mathrm{C}$ ), L2200 autosampler (sample injection volume $60 \mu \mathrm{L}$ ), Duratec vacuum degasser and reverse-phase column Merck LiChroCART, packed with LiChrospher 100 RP18 $(125 \mathrm{~mm} \times 4 \mathrm{~mm} \times 5 \mu \mathrm{m})$. The chromatographic elution conditions were as follows: $\mathrm{A}: \mathrm{B}=$ 70:30 (phenol) and 30:70 (ibuprofen), where $\mathrm{A}$ is an aqueous solution of $\mathrm{H}_{3} \mathrm{PO}_{4}(\mathrm{pH} 2.8$ ) and $\mathrm{B}$ is methanol, at $1.0 \mathrm{~mL} \mathrm{~min}{ }^{-1}$ flow rate. These conditions gave a column dead time of $1.2 \mathrm{~min}$ and retention times of $5.2 \mathrm{~min}$ for phenol and $5.7 \mathrm{~min}$ for ibuprofen (IBAP had a retention time of 6.0 min under the ibuprofen elution conditions). The detection wavelengths were set at $210 \mathrm{~nm}$ (phenol), $222 \mathrm{~nm}$ (ibuprofen) and $258 \mathrm{~nm}$ (IBAP), respectively.

\subsection{Monitoring of dissolved $\mathrm{Fe}(\mathrm{II}), \mathrm{Fe}(\mathrm{III})$ and $\mathrm{H}_{2} \mathrm{O}_{2}$}

The determination of dissolved (leached) iron (Sandell 1950) and of the amount of residual $\mathrm{H}_{2} \mathrm{O}_{2}$ in solution was carried out with colorimetric procedures. At scheduled reaction times, samples were withdrawn from the reaction mixture and filtered as mentioned above to remove suspended ZVI. In these experiments methanol was not used as quencher to avoid analytical biases, thus the following determinations were done soon after sample withdrawal. Absorbance measurements were carried out with a Varian Cary 100 Scan double-beam UV-Vis spectrophotometer, using Hellma quartz cuvettes with $1 \mathrm{~cm}$ optical path length.

Dissolved Fe(II) was determined by exploiting its reaction with o-phenanthroline that yields a red-orange complex (Sandell 1950). Operationally, $5 \mathrm{~mL}$ of the filtered sample were introduced into a $10 \mathrm{~mL}$ flask together with $1.82 \mathrm{~mL}$ of $0.011 \mathrm{M}$ o-phenanthroline solution, $\mathrm{H}_{2} \mathrm{SO}_{4}$ to reach $\mathrm{pH} \mathrm{2,} \mathrm{and} \mathrm{ultra-pure} \mathrm{water} \mathrm{to} \mathrm{volume.} \mathrm{To} \mathrm{ensure} \mathrm{a} \mathrm{complete} \mathrm{reaction} \mathrm{between} \mathrm{Fe}(\mathrm{II})$ and phenanthroline, a 5 min reaction time was allowed before analysis of the colored solutions at 510 $\mathrm{nm}$ (absorption maximum of the complex). The quantification of dissolved Fe(III) used the reaction with the thiocyanate anion to form a red complex. In a $10 \mathrm{~mL}$ flask we introduced $5 \mathrm{~mL}$ of filtered sample, $2 \mathrm{~mL}$ of aqueous $\mathrm{KSCN}\left(3.0 \times 10^{-2} \mathrm{M}\right), \mathrm{HCl}$ to obtain a final concentration of 
0.1 M, and water to volume. To avoid color fading, the absorbance of the colored solution was measured promptly at $457 \mathrm{~nm}$ (Sandell 1950).

Hydrogen peroxide was determined with the peroxidase - 4-aminoantipyrine method (Frew et al. 1983). This method uses a color-forming reagent in the presence of $\mathrm{H}_{2} \mathrm{O}_{2}$, and the reagent is prepared by dissolving $0.100 \mathrm{~g}$ 4-aminoantipyrine, $0.234 \mathrm{~g}$ phenol, $0.7112 \mathrm{~g} \mathrm{NaH}_{2} \mathrm{PO}_{4}, 0.2201 \mathrm{~g}$ $\mathrm{Na}_{2} \mathrm{HPO}_{4}$, and a spatula-tip amount of horseradish peroxidase in $100 \mathrm{~mL}$ ultra-pure water. In a 10 $\mathrm{mL}$ flask we then placed $2 \mathrm{~mL}$ of the color-forming reagent, $2 \mathrm{~mL}$ of the filtered sample, and water to volume. Although the solution quickly became colored due to the formation of the quinoneimine dye, it had to rest for 5 minutes before measuring the absorbance at $505 \mathrm{~nm}$ (Frew et al. 1983; Minella et al. 2016).

\section{Results and Discussion}

Preliminary experiments were carried out to assess a possible adsorption of either phenol or ibuprofen on ZVI at the used loadings, which could be excluded. Moreover, negligible degradation of the two substrates was observed in the presence of $\mathrm{ZVI}$ alone or $\mathrm{H}_{2} \mathrm{O}_{2}$ alone at the concentration values and time scales used in this work. The ZVI-Fenton process was first optimized by using phenol as model molecule, and these optimized conditions were then chosen to study and carry out the degradation of ibuprofen. The time scale of the experiments was kept within one hour, the reason being that slower reactions are little interesting in the context of water treatment.

Whenever feasible, in this work we used $\mathrm{HClO}_{4}$ to adjust $\mathrm{pH}$. The rationale is that $\mathrm{ClO}_{4}{ }^{-}$does not scavenge ${ }^{\circ} \mathrm{OH}$ significantly (Buxton et al. 1988), which explains why $\mathrm{HClO}_{4}$ is so widely used while studying AOPs. $\mathrm{HClO}_{4}$ cannot, however, be used in practical water-treatment applications due to the toxicity of its counter-ion (Kumarathilaka et al. 2016). In the case of Fenton water treatment, the chosen real-world acid would most likely be $\mathrm{H}_{2} \mathrm{SO}_{4}$ (Minella et al. 2018). Actually $\mathrm{SO}_{4}{ }^{2-}$ does not scavenge ${ }^{\circ} \mathrm{OH}$, but the significant reaction between $\mathrm{HSO}_{4}{ }^{-}$and ${ }^{\circ} \mathrm{OH}$ (Buxton et al. 1988) prevents a straightforward study of the process at $\mathrm{pH} 2$. Moreover, an effect of $\mathrm{HSO}_{4}{ }^{-}$on the degradation kinetics at pH 3 may not be totally excluded either. Our use of $\mathrm{HClO}_{4}$ was thus motivated by the need of obtaining unbiased results as far as the $\mathrm{pH}$ effect is concerned, which allows for the comparison of the process performance at different $\mathrm{pH}$ values. However, in the runs carried out with actual wastewater as reaction matrix we used $\mathrm{H}_{2} \mathrm{SO}_{4}$ to adjust $\mathrm{pH}$, to better 
simulate a real-world scenario. Also note that error bounds are not reported in the plots for readability issues, but experimental reproducibility was in the order of $10-15 \%$.

\subsection{Degradation of phenol as model molecule}

The optimal $\mathrm{pH}$ value of the Fenton reaction is often around 3, which may be a problem in the framework of both process operation (need to acidify and neutralize the system, with production of saline wastes or precipitates to be disposed of) and process costs (Minella et al. 2018). Therefore, it is very interesting to see whether and in which circumstances the ZVI-Fenton process may be active at $\mathrm{pH}>3$. Fig. 2 reports the $\mathrm{pH}$ trend of the ZVI-Fenton phenol degradation ( $5 \mu \mathrm{M}$ initial phenol concentration). Note that the amount of $\mathrm{HClO}_{4}$ used to fix the suspension $\mathrm{pH}$ from 2 to 4 was high enough to buffer the system against $\mathrm{pH}$ variations. In contrast, at $\mathrm{pH} 5$ or above it was necessary to use a buffer to fix $\mathrm{pH}$ instead of $\mathrm{HClO}_{4}$. A phosphate buffer was chosen in this case, because of the limited ability of $\mathrm{H}_{3} \mathrm{PO}_{4}$ and of the $\mathrm{H}_{2} \mathrm{PO}_{4}{ }^{-}, \mathrm{HPO}_{4}{ }^{2-}$ and $\mathrm{PO}_{4}{ }^{3-}$ ions to scavenge ${ }^{\circ} \mathrm{OH}$ (Buxton et al. 1988). It is important to operate at constant $\mathrm{pH}( \pm 0.3$ units in our case) in the framework of the Fenton technique, because of the considerable $\mathrm{pH}$ effect on degradation that is quite apparent in the figure. Variations in the $\mathrm{pH}$ values during the reaction may be induced by the Fenton process itself (e.g., reactions 1,2), but also by the carboxylic acids arising from the oxidation of phenol and similar compounds (Le et al. 2017). Curiously, it was possible to achieve effective ZVI-Fenton degradation of $0.1 \mathrm{mM}$ phenol at initial pH 7 (unbuffered, see Fig. 1-ESM in the Electronic Supplementary Material, hereafter ESM), only because the $\mathrm{pH}$ of the system quickly dropped down to 3.5 and triggered the reaction. The $\mathrm{pH}$ drop in the unbuffered system was more limited when $5 \mu \mathrm{M}$ phenol was used instead of $0.1 \mathrm{mM}$ (data not shown), most likely because of lower formation of $\mathrm{pH}$-modifying intermediates at lower phenol concentration. In the presence of phosphate buffer, very little degradation of 0.1 $\mathrm{mM}$ phenol was observed at $\mathrm{pH}$ 7. In addition to the loss of Fenton reactivity at circumneutral $\mathrm{pH}$, phosphate ions may bind to iron oxide layers coating the ZVI surface, and then act as a competitive ligand toward surface reactions. This side effect becomes more pronounced at high $\mathrm{pH}$, as binding of phosphates to metal oxides increases with increasing pH (Usman et al. 2018).

Looking again at Fig. 2, it is clear that the most effective degradation was obtained at pH 3. However, total phenol degradation was also achieved at $\mathrm{pH} 4$ with comparable (albeit slightly slower) kinetics than at $\mathrm{pH}$ 3. The degradation system lost performance at $\mathrm{pH} 5$ (in which case phenol degradation stopped at $\sim 85 \%$ ) and even more at $\mathrm{pH} 6$, while poor degradation was also observed at pH 2. Finally, the ZVI-Fenton system was not operational at (buffered) $\mathrm{pH} 7$. The 
figure thus shows that under the used conditions ( $5 \mu \mathrm{M}$ phenol, $\left.50 \mu \mathrm{M} \mathrm{H}_{2} \mathrm{O}_{2}, 0.01 \mathrm{~g} \mathrm{~L}^{-1} \mathrm{ZVI}\right)$ it would be possible to raise the operational $\mathrm{pH}$ from 3 to 4 with very little loss in performance (within experimental uncertainty), but with a considerable saving of $\mathrm{pH}$-fixing reagents.

In the case of $\mathrm{pH} 5$ and 6 the degradation of phenol was not complete, but one could try and find different conditions of $\mathrm{H}_{2} \mathrm{O}_{2}$ concentration and/or ZVI loading by which to bring degradation to completion or near completion. Considering that incomplete degradation could be caused by an insufficient amount of Fenton reagents, the most obvious approach was to increase either the $\mathrm{H}_{2} \mathrm{O}_{2}$ concentration at constant ZVI loading or, conversely, the ZVI loading at constant $\mathrm{H}_{2} \mathrm{O}_{2}$. Results obtained at pH 5 are reported in the ESM, in Fig. 2-ESM (increase of $\mathrm{H}_{2} \mathrm{O}_{2}$ ) and Fig. 3$\boldsymbol{E S M}$ (increase of ZVI). Increasing $\mathrm{H}_{2} \mathrm{O}_{2}$ above the $50 \mu \mathrm{M}$ level caused an improved phenol degradation, which reached an optimum at $\left[\mathrm{H}_{2} \mathrm{O}_{2}\right]=0.5-1 \mathrm{mM}$. A further increase in $\mathrm{H}_{2} \mathrm{O}_{2}$ concentration was actually detrimental. A similar scenario was observed when increasing ZVI, with an optimum loading of $0.04 \mathrm{~g} \mathrm{~L}^{-1}$ that produced complete phenol degradation.

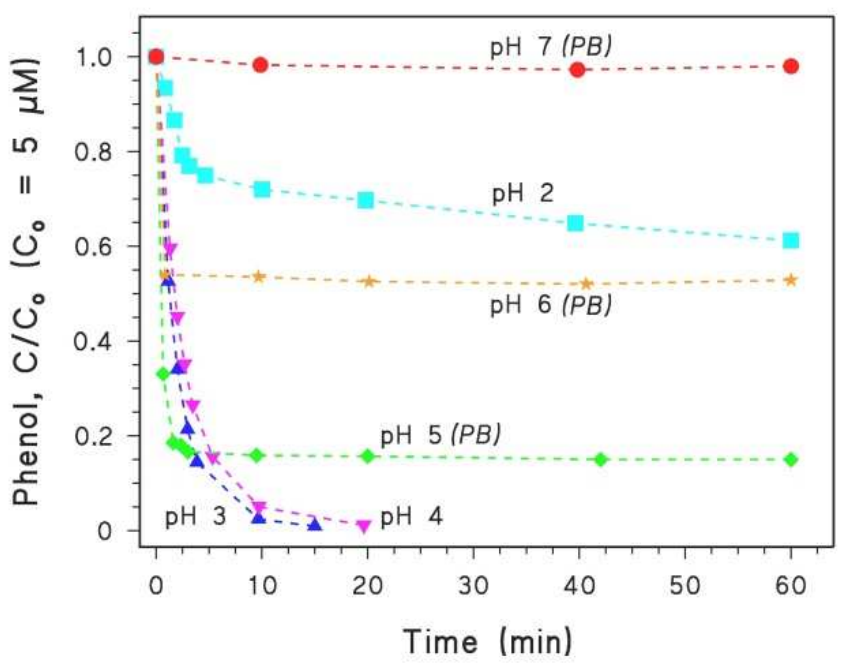

Fig. 2 Degradation of phenol (initial concentration $5 \mu \mathrm{M})$ in the presence of the ZVI-Fenton reagent $\left(50 \mu \mathrm{M} \mathrm{H}_{2} \mathrm{O}_{2}, 0.01 \mathrm{~g} \mathrm{~L}^{-1}\right.$ $\mathrm{ZVI})$ at different $\mathrm{pH}$ values. $\mathrm{PB}=$ phosphate buffer $\left(10 \mathrm{mM}\right.$ total concentration, mixtures of $\mathrm{H}_{3} \mathrm{PO}_{4}+\mathrm{NaH}_{2} \mathrm{PO}_{4}$ or of $\mathrm{NaH}_{2} \mathrm{PO}_{4}$ $+\mathrm{Na}_{2} \mathrm{HPO}_{4}$ ), used to adjust $\mathrm{pH}$. When the phosphate buffer was not used, $\mathrm{pH}$ was adjusted with $\mathrm{HClO}_{4}$.

The same approach was followed at $\mathrm{pH}$ 6, where the conditions reported in Fig. 2 caused only $\sim 50 \%$ phenol degradation. Although complete degradation at $\mathrm{pH} 6$ could not be achieved, the degradation percentage could be brought to $80 \%$ by increasing either $\mathrm{H}_{2} \mathrm{O}_{2}$ (optimal concentration of 0.5-1 mM, Fig. 4-ESM) or ZVI (optimal loading of $0.02 \mathrm{~g} \mathrm{~L}^{-1}$, Fig. 5-ESM). The main reason for finding optimal values of $\mathrm{H}_{2} \mathrm{O}_{2}$ concentration and ZVI loading at both $\mathrm{pH} 5$ and 6 , above 
which a poorer degradation performance was observed, is that on the one hand the two species are needed to produce ${ }^{\circ} \mathrm{OH}$, but on the other hand they both have a reducing behavior that allows for ${ }^{\circ} \mathrm{OH}$ scavenging (Gligorovski et al. 2015; Buxton et al. 1988). The optimum concentration/loading is thus the best trade-off between the enhancement of the Fenton process and the limitation of ${ }^{\bullet} \mathrm{OH}$ consumption.

Overall, the results obtained so far suggest that complete phenol degradation by ZVI-Fenton could be achieved at $\mathrm{pH} 3-5$, and $80 \%$ degradation at $\mathrm{pH}$ 6. Successful operation at $\mathrm{pH}>4$ required an increase in the concentration/loading of the reagents $\left(\mathrm{H}_{2} \mathrm{O}_{2}\right.$ and $\left.\mathrm{ZVI}\right)$, which in turn allowed for saving acids and bases for $\mathrm{pH}$ adjustment. The best trade-off between $\mathrm{H}_{2} \mathrm{O}_{2} / \mathrm{ZVI}$ and acids/bases consumption depends on several issues. First of all, the consumption of acids and bases in real applications depends on the buffer capacity of the wastewater: as a rule of thumb, the better the wastewater is pre-treated before Fenton operation (thereby eliminating organic matter and inorganic ions), the easier is to adjust $\mathrm{pH}$ afterwards (Minella et al. 2018). Moreover, acidification followed by neutralization produces a somewhat saline solution that, depending on the salt content, may cause problems in some scenarios (e.g., the reuse of wastewater in agriculture) $(\mathrm{Wu}$ et al. 2014). In the latter case, it might be better to operate at relatively high $\mathrm{pH}$ even if this entails a higher $\mathrm{H}_{2} \mathrm{O}_{2} / Z V I$ consumption.

\subsection{ZVI-Fenton degradation of ibuprofen}

To carry out the degradation of ibuprofen, the conditions that were already shown to induce effective phenol transformation were chosen as well. Note that ibuprofen carries a carboxylic group with $\mathrm{pK}_{\mathrm{a}} \sim 5$ (Park et al. 2018), thus the $\mathrm{pH}$ trend of the Fenton reaction is combined with the acid-base equilibrium of the substrate. Therefore, it is hardly surprising to find somewhat dissimilar pH trend for ibuprofen degradation (see Fig. 3) as compared to phenol. The very good degradation of ibuprofen at pH 2 is, unfortunately, of limited interest in the context of wastewater treatment. With $5 \mu \mathrm{M}$ ibuprofen, $50 \mu \mathrm{M} \mathrm{H}_{2} \mathrm{O}_{2}$ and $0.01 \mathrm{~g} \mathrm{~L}^{-1} \mathrm{ZVI}$, good degradation performance could be observed in the $\mathrm{pH}$ range 3-5, while the process lost efficiency at $\mathrm{pH} 6$ and 7. While practically complete ibuprofen degradation could be achieved in $1 \mathrm{~h}$ at pH with $50 \mu \mathrm{M} \mathrm{H}_{2} \mathrm{O}_{2}$ and $0.01 \mathrm{~g} \mathrm{~L}^{-1} \mathrm{ZVI}$, it was necessary to increase $\mathrm{H}_{2} \mathrm{O}_{2}$ to at least $100 \mu \mathrm{M}$ to achieve the same result at pH 5 (Fig. 4a). Under such conditions, the optimum ZVI loading was 0.01-0.02 $\mathrm{g} \mathrm{L}^{-1}$ (Fig. 4b). 


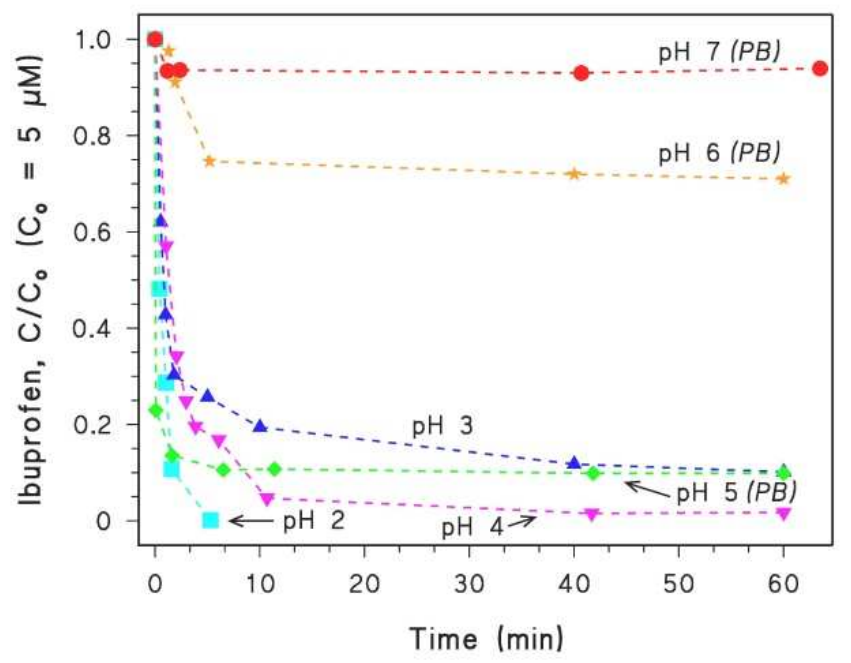

Fig. 3 Degradation of $5 \mu \mathrm{M}$ ibuprofen in the presence of the ZVI-Fenton reagent $\left(50 \mu \mathrm{M} \mathrm{H}_{2} \mathrm{O}_{2}, 0.01 \mathrm{~g} \mathrm{~L} \mathrm{ZVI}^{-1}\right.$ at different pH values. $P B=$ phosphate buffer $\left(10 \mathrm{mM}, \mathrm{H}_{3} \mathrm{PO}_{4}+\mathrm{NaH}_{2} \mathrm{PO}_{4}\right.$ or $\left.\mathrm{NaH}_{2} \mathrm{PO}_{4}+\mathrm{Na}_{2} \mathrm{HPO}_{4}\right)$, used to adjust $\mathrm{pH}$ in alternative to $\mathrm{HClO}_{4}$.
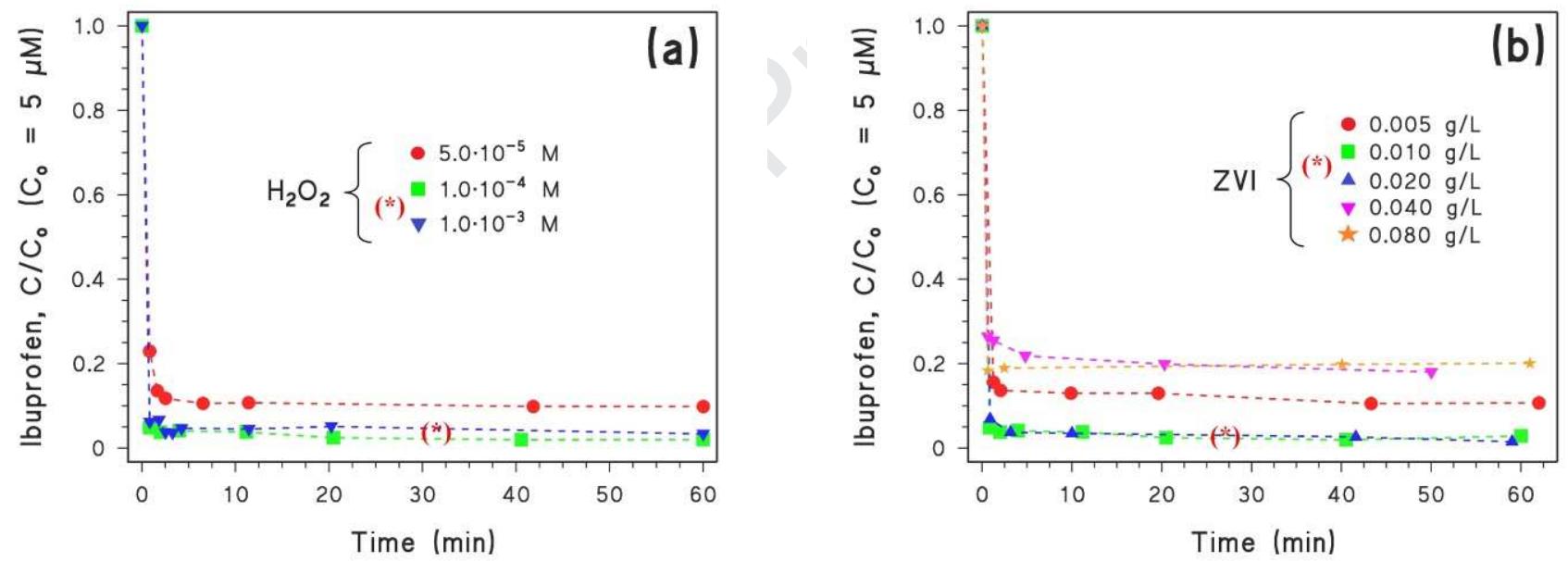

Fig. 4 Degradation of $5 \mu \mathrm{M}$ ibuprofen in the presence of the ZVI-Fenton reagent at pH 5, adjusted with $\mathrm{H}_{3} \mathrm{PO}_{4}+\mathrm{NaH}_{2} \mathrm{PO}_{4}(10$ $\mathrm{mM}$ total concentration). (a) Time trend with $0.01 \mathrm{~g} \mathrm{~L}^{-1} \mathrm{ZVI}$ and variable $\mathrm{H}_{2} \mathrm{O}_{2}$. (b) Time trend with $0.1 \mathrm{mM} \mathrm{H}_{2} \mathrm{O}_{2}$ and variable ZVI.

Interestingly, effective degradation of both $5 \mu \mathrm{M}$ phenol and $5 \mu \mathrm{M}$ ibuprofen could be achieved at pH 4 in the presence of $50 \mu \mathrm{M} \mathrm{H}_{2} \mathrm{O}_{2}$ and $0.01 \mathrm{~g} \mathrm{~L}^{-1} \mathrm{ZVI}$ (Figs. 2,3). At pH 5 the optimum conditions for phenol and ibuprofen were somewhat different, but effective degradation could be obtained in both cases with 50-100 $\mu \mathrm{M} \mathrm{H}_{2} \mathrm{O}_{2}$ and $0.02 \mathrm{~g} \mathrm{~L}^{-1}$ ZVI (Figs. 3-ESM and 4). The possibility to degrade different compounds under the same range of operational conditions is obviously important, as it indicates a good level of robustness of the treatment process. 
In the case of $\mathrm{pH} \mathrm{6,} \mathrm{it} \mathrm{was} \mathrm{not} \mathrm{possible} \mathrm{to} \mathrm{achieve} \mathrm{good} \mathrm{ibuprofen} \mathrm{degradation} \mathrm{with} \mathrm{a} \mathrm{single}$ addition of $\mathrm{H}_{2} \mathrm{O}_{2}$. The issue is that by increasing the $\mathrm{H}_{2} \mathrm{O}_{2}$ concentration above $50 \mu \mathrm{M}$, degradation was initially improved, presumably due to enhanced reactive species formation. However, the ${ }^{\bullet} \mathrm{OH}$ scavenging by $\mathrm{H}_{2} \mathrm{O}_{2}$ itself soon gained importance. Therefore, the ZVI-Fenton degradation of ibuprofen never exceeded $50 \%$ at $\mathrm{pH} 6$, irrespective of the initial $\left[\mathrm{H}_{2} \mathrm{O}_{2}\right]$ used. Moreover, varying ZVI gave little help.

In these cases, it is possible to limit the ${ }^{\circ} \mathrm{OH}$ scavenging action of $\mathrm{H}_{2} \mathrm{O}_{2}$ by carrying out multiple $\mathrm{H}_{2} \mathrm{O}_{2}$ additions (Minella et al. 2018). The rationale is that if a large $\mathrm{H}_{2} \mathrm{O}_{2}$ amount is added in a single step, the resulting high concentration favors ${ }^{\circ} \mathrm{OH}$ scavenging. In contrast, if the same amount is divided into multiple additions, the concentration of $\mathrm{H}_{2} \mathrm{O}_{2}$ (which is degraded in the Fenton process) at any given time is never too high and scavenging is limited (Minella et al. 2018; $\mathrm{Li}$ and Goel 2010, Harimurti et al. 2010). Coherently, with a total of six $\mathrm{H}_{2} \mathrm{O}_{2}$ additions (one every 10 minutes) it was possible to achieve up to $90 \%$ ibuprofen degradation by properly adjusting the ZVI loading (see Fig. 5a).
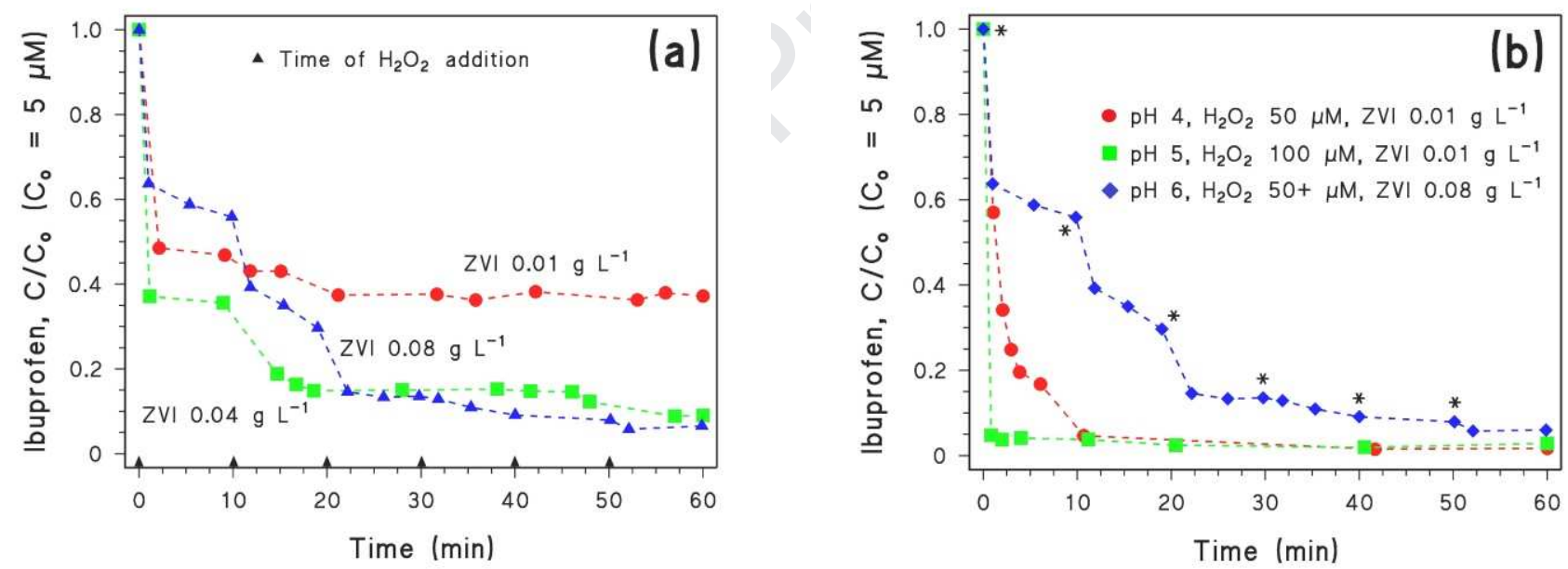

Fig. 5 (a) Time trend of $5 \mu \mathrm{M}$ ibuprofen with ZVI-Fenton at pH 6, adjusted with $\mathrm{NaH}_{2} \mathrm{PO}_{4}+\mathrm{Na}_{2} \mathrm{HPO}_{4}(10 \mathrm{mM}$ total concentration). Multiple additions of $\mathrm{H}_{2} \mathrm{O}_{2}$ were carried out, one every 10 min reaction time. The initial $\mathrm{H}_{2} \mathrm{O}_{2}$ concentration was $50 \mu \mathrm{M}$ and each added amount corresponded to $3 \mu \mathrm{M}$, thereby yielding a cumulated $65 \mu \mathrm{M} \mathrm{H}_{2} \mathrm{O}_{2}$ concentration at $50 \mathrm{~min}$. (b) Time trend of ibuprofen under optimal conditions (specified in the legend) at $\mathrm{pH} 4$ (adjusted with $\mathrm{HClO}_{4}$ ), 5 and 6 (adjusted with $\mathrm{PB}$ ). "50+" at $\mathrm{pH} 6$ means that multiple $\mathrm{H}_{2} \mathrm{O}_{2}$ additions were carried out, starting from $50 \mu \mathrm{M}$ and up to a cumulated $65 \mu \mathrm{M}$. The asterisks show the $\mathrm{H}_{2} \mathrm{O}_{2}$ addition times

The optimal conditions for ibuprofen degradation are summarized in Fig. $5 \mathbf{b}$ for $\mathrm{pH} 4$ (with 50 $\mu \mathrm{M} \mathrm{H}_{2} \mathrm{O}_{2}$ and $0.01 \mathrm{~g} \mathrm{~L}^{-1} \mathrm{ZVI}$ ), pH 5 (with $100 \mu \mathrm{M} \mathrm{H}_{2} \mathrm{O}_{2}$ and $0.01 \mathrm{~g} \mathrm{~L}^{-1} \mathrm{ZVI}$ ) and pH 6 (with several $\mathrm{H}_{2} \mathrm{O}_{2}$ additions, corresponding to a cumulated concentration of $65 \mu \mathrm{M} \mathrm{H}_{2} \mathrm{O}_{2}$, and $0.08 \mathrm{~g}$ $\left.\mathrm{L}^{-1} \mathrm{ZVI}\right)$. It was thus possible to increase the operational $\mathrm{pH}$ of Fenton degradation, but as already 
seen with phenol, the trade-off was again an increased consumption of reactants $\left(\mathrm{H}_{2} \mathrm{O}_{2}\right.$ and/or ZVI). The possibility to achieve good degradation under different conditions is, however, very interesting because it enhances the flexibility of the treatment technique. Depending on the wastewater quality requirements, it is in fact possible to choose either to save $\mathrm{ZVI} / \mathrm{H}_{2} \mathrm{O}_{2}$, or to save the $\mathrm{pH}$-fixing reagents. For instance, wastewater salinity is an issue for agricultural reuse but it is less so for, e.g., seawater discharge.

Overall, comparison between the ZVI-Fenton degradation performance of phenol and ibuprofen shows more similarities than differences. Although ibuprofen was more effectively degraded than phenol at $\mathrm{pH} \mathrm{2,} \mathrm{and} \mathrm{the} \mathrm{reverse} \mathrm{happened} \mathrm{at} \mathrm{pH} 3$, these conditions are of limited interest in practical applications. At $\mathrm{pH} 4$ and above, the degradation trend was quite similar for both compounds. Complete degradation at pH 4 was easily achieved in both cases, while the same result at $\mathrm{pH} 5$ required more careful optimization of the system conditions. In contrast, and again for both compounds, the degradation at $\mathrm{pH} 6$ was extensive after optimization of the system, but not quantitative. Interestingly, the optimized degradation conditions of phenol and ibuprofen were very similar, especially at $\mathrm{pH} 4$ and 5. Finally, practically no degradation of either compound could be achieved at $\mathrm{pH}$ 7. These findings suggest that the ZVI-Fenton reactivity varies with $\mathrm{pH}$, but it does so in a rather predictable way. Such a behavior can potentially $(i)$ make it easier to find optimal (and hopefully similar) degradation conditions for other compounds, and (ii) allow for the setting up of a single treatment method that could work in the presence of pollutant mixtures, which is the case for most real wastewaters. Therefore, ZVI-Fenton appears as a reasonably promising technique for the degradation of pollutants.

\subsection{Time evolution of $\mathrm{Fe}(\mathrm{II}), \mathrm{Fe}(\mathrm{III})$ and $\mathrm{H}_{2} \mathrm{O}_{2}$}

The time evolution of the main inorganic species involved in the Fenton reaction $\left(\mathrm{H}_{2} \mathrm{O}_{2}, \mathrm{Fe}\right.$ (II) and $\mathrm{Fe}(\mathrm{III})$ ) was studied spectrophotometrically in the $\mathrm{pH}$ interval 3-5, under optimal conditions for ibuprofen degradation (see Figs. 3 and 5b). The $\mathrm{H}_{2} \mathrm{O}_{2}$ trend at $\mathrm{pH} 6$ was more difficult to follow due to the need of carrying out multiple $\mathrm{H}_{2} \mathrm{O}_{2}$ additions to achieve reasonable degradation; hence, data at pH 6 are not reported. The $\mathrm{H}_{2} \mathrm{O}_{2}$ time trends are reported in Fig. 6a-c, and all show a $\mathrm{H}_{2} \mathrm{O}_{2}$ decrease that is consistent with the Fenton reaction. Dissolved Fe(II) initially occurred at higher concentration than Fe(III), which is reasonable given its higher solubility, but it soon disappeared due to oxidation by $\mathrm{H}_{2} \mathrm{O}_{2}$. This process accounts for the initial Fe(III) increase, while the subsequent decrease is most likely accounted for by the capture of Fe species by the ZVI surface. The Fe(III) trend at $\mathrm{pH} 3$ and long reaction times was less straightforward, possibly due 
to higher Fe(III) solubility at $\mathrm{pH} 3$ than at $\mathrm{pH} 4$ or 5 . Solubility issues would also account for the fact that dissolved $\mathrm{Fe}$ was lower at $\mathrm{pH} 4$ than at $\mathrm{pH} 3$. In contrast, the results at $\mathrm{pH} 5$ might be accounted for by the higher $\mathrm{H}_{2} \mathrm{O}_{2}$ concentration that was required to achieve ibuprofen degradation. A higher $\mathrm{H}_{2} \mathrm{O}_{2}$ level would enhance the $\mathrm{H}_{2} \mathrm{O}_{2}$ reaction with the ZVI surface, thereby increasing the concentration of dissolved Fe.

The dissolution of $\mathrm{Fe}$ from the solid surface may be a problem, when considering that concentration limits for total dissolved $\mathrm{Fe}$ in wastewater are enforced in many countries, and that they usually range between 1 and $2 \mathrm{mg}_{\mathrm{Fe}} \mathrm{L}^{-1}$. A comparison between the time trends of total $\mathrm{Fe}$ (i.e., $\mathrm{Fe}(\mathrm{II})+\mathrm{Fe}(\mathrm{III})$ ) in our experiments and the typical legislation limits is provided in Fig. 6d. It is shown that, in all conditions, the most stringent requirement was met after 30 min reaction time. In all these cases, after achieving total degradation of ibuprofen, there would be no need of residual Fe removal.
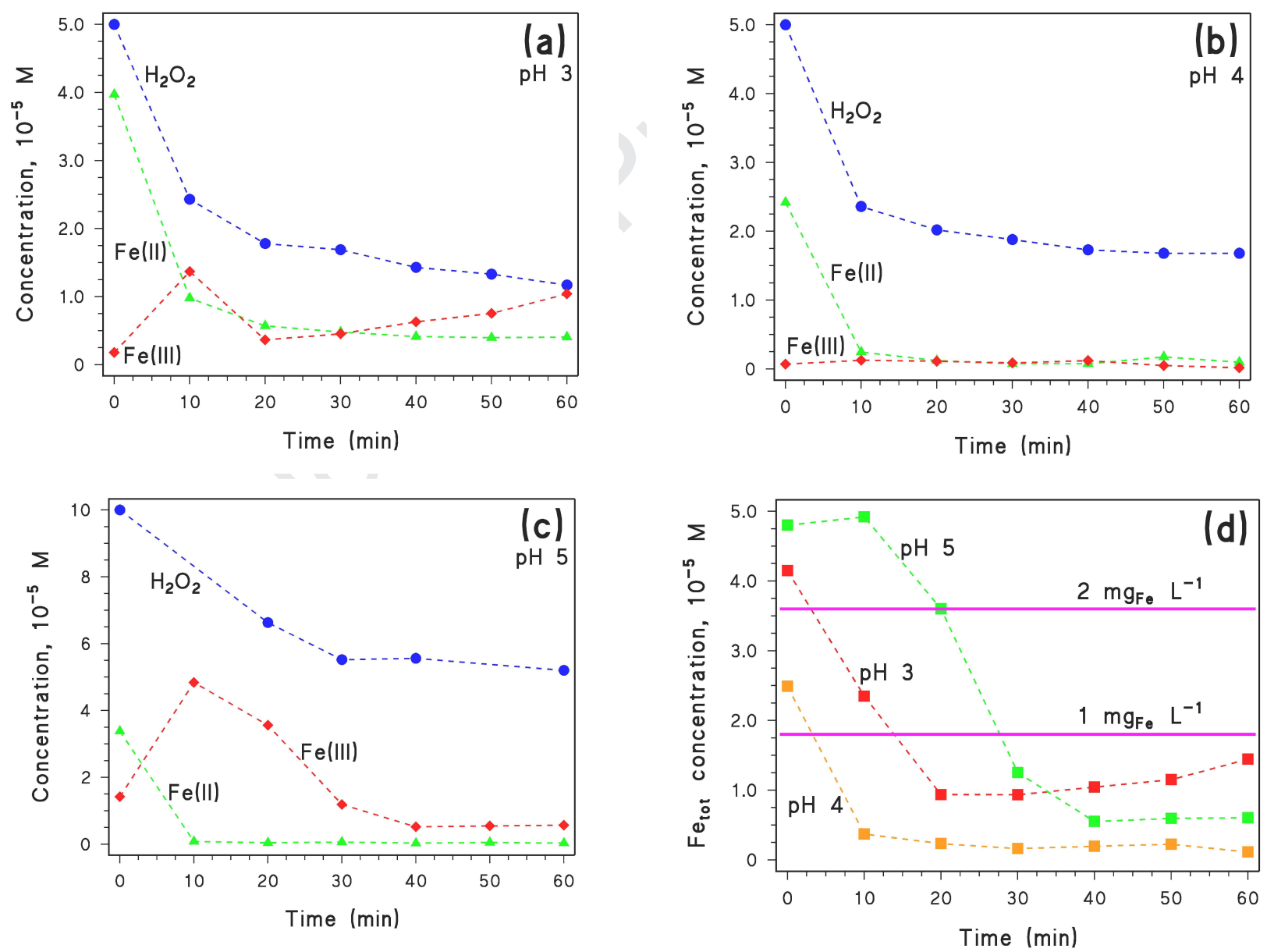

Fig. 6 Time trends of $\mathrm{H}_{2} \mathrm{O}_{2}, \mathrm{Fe}(\mathrm{II})$ and $\mathrm{Fe}(\mathrm{III})$ at: (a) $\mathrm{pH} 3$ (with $5 \mu \mathrm{M}$ ibuprofen, $50 \mu \mathrm{M} \mathrm{H}_{2} \mathrm{O}_{2}$ and $0.01 \mathrm{~g} \mathrm{~L} \mathrm{Z}^{-1} \mathrm{ZVI}$ ); (b) pH 4

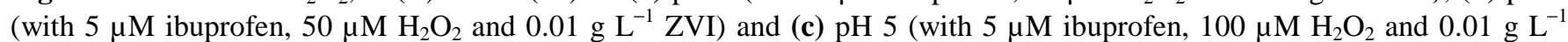
ZVI). (d) Time trends of total Fe (Fe(II) + Fe(III)) at pH 3-5 as per the previous runs, compared with typical limits enforced for Fe content in wastewater. 


\subsection{Assessment of the 4-isobutylacetophenone (IBAP) time trend}

It is well known in the framework of water treatment that the degradation of the initial pollutant is important, but it is not the end of the story. Indeed, transformation intermediates are usually formed, and some of them may be more harmful (e.g., toxic and/or mutagenic) than the primary compound (Fernández-Alba et al. 2002). In the case of ibuprofen, IBAP is the most toxic transformation intermediate (Miranda et al. 1991). Moreover, IBAP is commercially available as standard, and its time trend can be quantitatively monitored.

Under the optimal conditions for ibuprofen degradation at $\mathrm{pH} 4\left(50 \mu \mathrm{M} \mathrm{H}_{2} \mathrm{O}_{2}, 0.01 \mathrm{~g} \mathrm{~L}^{-1} \mathrm{ZVI}\right)$, IBAP formation could be detected but with low yield (see Fig. 7a): the maximum IBAP concentration was $<0.5 \%$ of the initial ibuprofen. Moreover, IBAP also underwent degradation with comparable kinetics as the parent compound, and it practically disappeared within $1 \mathrm{~h}$ reaction time. At pH 5 under optimal conditions $\left(100 \mu \mathrm{M} \mathrm{H}_{2} \mathrm{O}_{2}, 0.01 \mathrm{~g} \mathrm{~L}^{-1} \mathrm{ZVI}\right)$ and at $\mathrm{pH}$, the concentration of IBAP was always below the detection limit.
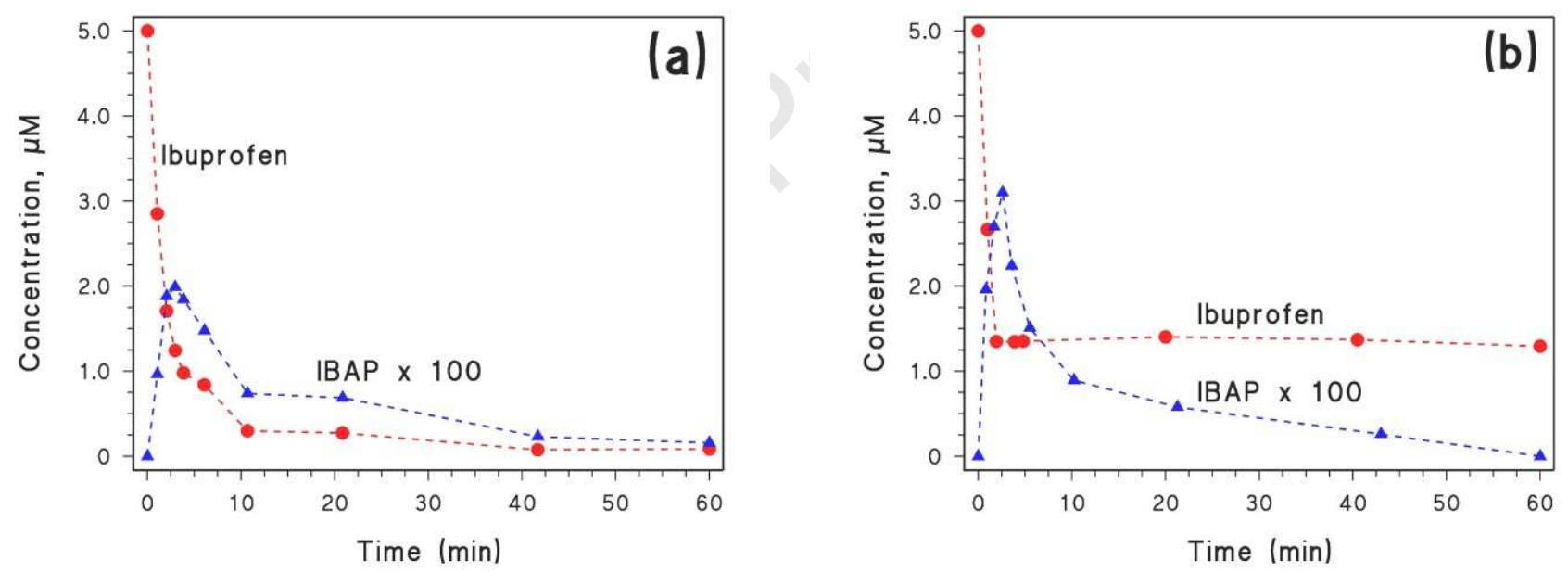

Fig. 7 Time trends of $5 \mu \mathrm{M}$ ibuprofen and of 4-isobutylacetophenone (IBAP) with the ZVI-Fenton reagent at: (a) pH $4\left(50 \mu \mathrm{M} \mathrm{H}_{2} \mathrm{O}_{2}, 0.01 \mathrm{~g} \mathrm{~L}^{-1} \mathrm{ZVI}\right.$, pH adjusted by $\left.\mathrm{HClO}_{4}\right)$, and (b) $\mathrm{pH} 5\left(100 \mu \mathrm{M} \mathrm{H}_{2} \mathrm{O}_{2}, 0.04 \mathrm{~g} \mathrm{~L}^{-1} \mathrm{ZVI}\right.$, pH adjusted by phosphate buffer). Note that the IBAP concentration was multiplied by 100 for plot readability issues.

In contrast, it was possible to quantify IBAP at $\mathrm{pH} 5$ (at concentration levels that never exceeded $1 \%$ of the initial substrate) under circumstances where the degradation of ibuprofen was incomplete $\left(100 \mu \mathrm{M} \mathrm{H}_{2} \mathrm{O}_{2}\right.$ and $0.04 \mathrm{~g} \mathrm{~L}^{-1} \mathrm{ZVI}$, see Fig. 7b). In this case, IBAP peaked after 3 min reaction time and disappeared after 1 hour, when $\sim 25 \%$ of the initial ibuprofen was still occurring in the reaction system. 
These findings suggest that IBAP was formed with very low yields by the ZVI-Fenton process, and its stability towards oxidative degradation was comparable to $(\mathrm{pH} 4)$ or even lower than $(\mathrm{pH}$ 5) that of the parent compound. Therefore, conditions aimed at achieving complete ibuprofen degradation can easily ensure the disappearance of IBAP, which is the most concerning transformation intermediate.

\subsection{Ibuprofen degradation in actual wastewater}

The degradation of ibuprofen was also studied in a wastewater sample that had undergone both primary and secondary (activated sludge) treatments. The two treatment steps ensure the elimination of a considerable fraction of organic matter and inorganic ions (Minella et al. 2018). Different conditions of initial $\mathrm{pH}$ (adjusted with $\mathrm{H}_{2} \mathrm{SO}_{4}$ ) and reagents concentrations were tested. Additionally, wastewater titration (see Fig. 6-ESM) provided insight into the amount of acid required to fix the initial $\mathrm{pH}$, which depends on the wastewater buffer capacity. Because an equivalent amount of base is needed to restore the initial conditions after treatment, the titration results also suggest the likely level of added salts in the process. The relevant results indicate that by fixing $\mathrm{pH}$ to 6 one consumed about half of the acid that was needed to fix $\mathrm{pH}$ to 3 . Moreover, there was little difference in acid consumption (and, therefore, in neutralized wastewater salinity) when fixing $\mathrm{pH}$ to either 4 or 5: in both cases, a 30-35\% acid saving would be observed compared to $\mathrm{pH} 3$.

The ibuprofen time trends in wastewater due to ZVI-Fenton degradation at different $\mathrm{pH}$ values are reported in Fig. 8. Different $\mathrm{H}_{2} \mathrm{O}_{2}$ concentrations and ZVI loadings were used in different $\mathrm{pH}$ conditions, following the optimization experiments described previously. To compensate for the decrease in degradation efficiency in wastewater vs. laboratory systems, which is caused by the occurrence of interfering agents in wastewater (mostly, ${ }^{\circ} \mathrm{OH}$ scavengers), multiple $\mathrm{H}_{2} \mathrm{O}_{2}$ additions were carried out at 10 min intervals (Minella et al. 2018). Each time, the $\mathrm{H}_{2} \mathrm{O}_{2}$ addition was equal to the amount added at zero time. It was used $50 \mu \mathrm{M} \mathrm{H}_{2} \mathrm{O}_{2}$ and $0.01 \mathrm{~g} \mathrm{~L}^{-1} \mathrm{ZVI}$ for $\mathrm{pH} 3$ and $\mathrm{pH} 4$, $100 \mu \mathrm{M} \mathrm{H}_{2} \mathrm{O}_{2}$ and $0.01 \mathrm{~g} \mathrm{~L}^{-1} \mathrm{ZVI}$ for $\mathrm{pH}$, as well as $100 \mu \mathrm{M} \mathrm{H}_{2} \mathrm{O}_{2}$ and $0.08 \mathrm{~g} \mathrm{~L}^{-1} \mathrm{ZVI}$ for $\mathrm{pH} 6$ and $\mathrm{pH} 7.6$ (the latter was the natural wastewater $\mathrm{pH}$; all $\mathrm{H}_{2} \mathrm{O}_{2}$ concentrations refer to the initial addition). The degradation of ibuprofen was equally effective at $\mathrm{pH} 3$ and 4, while the system considerably lost performance at $\mathrm{pH} 5$ despite the higher $\mathrm{H}_{2} \mathrm{O}_{2}$ concentration used. Moreover, operation at pH 6 gave very effective ibuprofen degradation, most likely because of the relatively high ZVI loading used in such conditions (by comparison, almost no degradation occurred at pH 6 with $0.01 \mathrm{~g} \mathrm{~L}^{-1} \mathrm{ZVI}$, data not shown). 
Note that it makes little sense to increase the ZVI loading to enhance degradation at $\mathrm{pH}$ 5: the limited difference in the equivalents of acid needed to adjust $\mathrm{pH}$ to either 4 or 5 (see Fig. 6-ESI) does not compensate for the reactivity drop, which makes operation at $\mathrm{pH} 4$ preferred. In contrast, operation at $\mathrm{pH} 6$ would allow for savings in $\mathrm{pH}$-fixing reagents.

When considering the $\mathrm{H}_{2} \mathrm{O}_{2}$ concentration in each addition and the number of additions required for ibuprofen degradation, the overall $\mathrm{H}_{2} \mathrm{O}_{2}$ consumption at $\mathrm{pH} 4$ (6 additions of $50 \mu \mathrm{M}$ reagent) was 1.5 times higher than at pH 6 ( 2 additions of $100 \mu \mathrm{M}$ reagent). Furthermore, the ZVI loading was 8 times higher at $\mathrm{pH} 6$ than at $\mathrm{pH} 4$. Finally, the ZVI-Fenton process was not operational at the natural wastewater $\mathrm{pH}$.

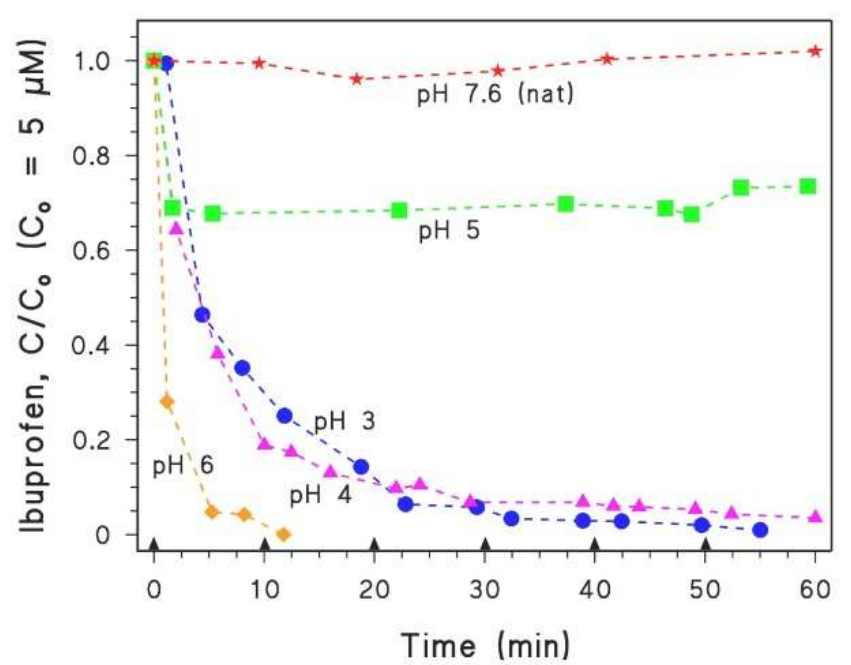

Fig. 8 Time trends of $5 \mu \mathrm{M}$ ibuprofen dissolved in actual wastewater, at different $\mathrm{pH}$ values. The following initial conditions of ZVI-Fenton reagents were used: $50 \mu \mathrm{M} \mathrm{H}_{2} \mathrm{O}_{2}$ and $0.01 \mathrm{~g} \mathrm{~L}^{-1} \mathrm{ZVI}$ for $\mathrm{pH} 3$ and $\mathrm{pH} \mathrm{4;} 100 \mu \mathrm{M} \mathrm{H}_{2} \mathrm{O}_{2}$ and $0.01 \mathrm{~g} \mathrm{~L}^{-1} \mathrm{ZVI}_{\text {for }}$ $\mathrm{pH} 5 ; 100 \mu \mathrm{M} \mathrm{H}_{2} \mathrm{O}_{2}$ and $0.08 \mathrm{~g} \mathrm{~L}^{-1} \mathrm{ZVI}$ for $\mathrm{pH} 6$ and $\mathrm{pH} 7.6$ (natural wastewater $\mathrm{pH}$ ). In all the cases, multiple additions of $\mathrm{H}_{2} \mathrm{O}_{2}$ were carried out, one every 10 min reaction time (see the black triangles, each one corresponding to a $\mathrm{H}_{2} \mathrm{O}_{2}$ addition time). Each time, the amount of added $\mathrm{H}_{2} \mathrm{O}_{2}$ was equal to that of the initial addition. The $\mathrm{pH}$ values were adjusted with $\mathrm{H}_{2} \mathrm{SO}_{4}$, except for the case of natural $\mathrm{pH}$ (no $\mathrm{H}_{2} \mathrm{SO}_{4}$ added). In all the cases, the $\mathrm{pH}$ variation during the reaction was within $\pm 0.3-0.4$ $\mathrm{pH}$ units.

\subsubsection{Cost analysis}

It is interesting to quantitatively assess the trade-offs of operating under the conditions that proved to be effective for the ZVI-Fenton degradation of ibuprofen in secondary wastewater ( $\mathrm{pH} \mathrm{3,4}$ and 6, see Fig. 8), from the point of view of process costs. Here only the cost of chemicals is considered, but this is usually the largest expense entry in Fenton operations (Balabanič et al. 2012). Costs are referred to the treatment of $1 \mathrm{~m}^{3}$ secondary wastewater, based on the 
performance of the experiments that are described in Fig. 8 and related discussion. The cost analysis results are reported in Table 3, and they show that operating costs for reagents follow the order $\mathrm{pH} 4<\mathrm{pH} 3<\mathrm{pH}$. The cost of $\mathrm{H}_{2} \mathrm{SO}_{4}$ dominates at $\mathrm{pH} 3$ and 4 , while ZVI prevails at $\mathrm{pH}$ 6. By comparison, the current cost of conventional wastewater treatment in Italy is $0.38 \$ \mathrm{~m}^{-3}$, but it does not ensure the removal of contaminants of emerging concern (Minella et al. 2018). The addition of a ZVI-Fenton step operated at $\mathrm{pH} 4$ to traditional treatment would entail an only moderate increase in treatment costs. ZVI-Fenton operation at $\mathrm{pH} 6$ would be more costly, but it has the advantage of reducing the salinity of treated wastewater. The choice criteria between the two $\mathrm{pH}$ values could depend on the wastewater fate (discharge or reuse), which might or might not justify the added costs of operating at $\mathrm{pH} 6$.

Table 3. Breakdown of reagents costs for wastewater treatment with ZVI-Fenton. Costs and amounts are referred to the treatment of $1 \mathrm{~m}^{3}$ secondary wastewater. $\mathrm{H}_{2} \mathrm{SO}_{4}$ is used to acidify, $\mathrm{CaO}$ to restore the initial $\mathrm{pH}$ after treatment.

\begin{tabular}{|c|c|c|c|}
\hline & pH 3 & pH 4 & pH 6 \\
\hline $\mathrm{ZVI}\left(\$ \mathrm{~m}^{-3}\right)^{\mathrm{a}}$ & $\begin{array}{l}0.008(10 \mathrm{~g} \text { of } 99 \% \\
\text { purity } \mathrm{Fe} \text { powder, at } \\
\left.800 \$ \mathrm{ton}^{-1}\right)\end{array}$ & $\begin{array}{l}0.008(10 \mathrm{~g} \text { of } 99 \% \\
\text { purity } \mathrm{Fe} \text { powder, } \\
\left.\text { at } 800 \$ \mathrm{ton}^{-1}\right)\end{array}$ & $\begin{array}{l}0.064(80 \mathrm{~g} \text { of } 99 \% \\
\text { purity } \mathrm{Fe} \text { powder, at } \\
\left.800 \$ \mathrm{ton}^{-1}\right)\end{array}$ \\
\hline $\mathrm{H}_{2} \mathrm{O}_{2}\left(\$ \mathrm{~m}^{-3}\right)^{\mathrm{a}}$ & $\begin{array}{l}0.009(20.7 \mathrm{~g} \text { of } 50 \% \\
\mathrm{w} / \mathrm{w} \mathrm{H}_{2} \mathrm{O}_{2} \text {, at } 435 \$ \\
\left.\text { ton }^{-1}\right)\end{array}$ & $\begin{array}{l}0.009(20.7 \mathrm{~g} \text { of } \\
50 \% \mathrm{w} / \mathrm{w} \mathrm{H}_{2} \mathrm{O}_{2} \text {, at } \\
\left.435 \$ \text { ton }^{-1}\right)\end{array}$ & $\begin{array}{l}0.006 \quad(13.8 \mathrm{~g} \text { of } \\
50 \% \mathrm{w} / \mathrm{w} \mathrm{H}_{2} \mathrm{O}_{2} \text {, at } \\
\left.435 \$ \text { ton }^{-1}\right)\end{array}$ \\
\hline $\mathrm{H}_{2} \mathrm{SO}_{4}\left(\$ \mathrm{~m}^{-3}\right)^{\mathrm{a}}$ & $\begin{array}{l}0.048(200 \mathrm{~g} \text { of } 96 \% \\
\mathrm{w} / \mathrm{w} \mathrm{H}_{2} \mathrm{SO}_{4} \text {, at } 240 \$ \\
\left.\text { ton }^{-1}\right)\end{array}$ & $\begin{array}{l}0.034(142 \mathrm{~g} \text { of } \\
96 \% \mathrm{w} / \mathrm{w} \quad \mathrm{H}_{2} \mathrm{SO}_{4}, \\
\left.\text { at } 240 \mathrm{ton}^{-1}\right)\end{array}$ & $\begin{array}{l}0.025(104 \mathrm{~g} \text { of } 96 \% \\
\text { w/w } \mathrm{H}_{2} \mathrm{SO}_{4} \text {, at } 240 \\
\left.\$ \text { ton }^{-1}\right)\end{array}$ \\
\hline $\mathrm{CaO}\left(\$ \mathrm{~m}^{-3}\right)^{\mathrm{a}}$ & $\begin{array}{l}0.013(108 \mathrm{~g} \text { of } 99 \% \\
\text { purity } \mathrm{CaO} \text {, at } 800 \$ \\
\left.\text { ton }^{-1}\right)\end{array}$ & $\begin{array}{l}0.009(75 \mathrm{~g} \text { of } 99 \% \\
\text { purity } \mathrm{CaO} \text {, at } 800 \\
\left.\$ \text { ton }^{-1}\right)\end{array}$ & $\begin{array}{l}0.007(58 \mathrm{~g} \text { of } 99 \% \\
\text { purity } \mathrm{CaO} \text {, at } 800 \$ \\
\left.\text { ton }^{-1}\right)\end{array}$ \\
\hline $\begin{array}{l}\text { Total reagents } \\
\operatorname{cost}\left(\$ \mathrm{~m}^{-3}\right)\end{array}$ & 0.078 & 0.060 & 0.101 \\
\hline
\end{tabular}

${ }^{\text {a }}$ Costs were derived from current market prices (http://www.made-in-china.com, last accessed December 2018). In the case of ZVI, it was considered the average price of high-purity iron powder. 


\section{Conclusions}

Effective degradation of ibuprofen was achieved by the ZVI-Fenton technique in the pH range 36 , under a variety of conditions of $\mathrm{H}_{2} \mathrm{O}_{2}$ concentration and ZVI loading. Interestingly, the same conditions would also ensure degradation of phenol as an additional model pollutant. The ability to degrade two different pollutants under similar conditions is a potential advantage for a treatment technology, because the method could be potentially extended to pollutant mixtures. However, the assessment of the ability of ZVI-Fenton to effectively degrade mixtures in actual wastewater is beyond the scope of the present work.

Overall, it appears that there is a trade-off between the saving of $\mathrm{pH}$-fixing reagents, enabled by operation at the higher $\mathrm{pH}$ values, and the higher amounts of $\mathrm{H}_{2} \mathrm{O}_{2}$ and/or ZVI required to achieve effective degradation at higher $\mathrm{pH}$. Choice criteria could involve cost considerations and additional requirements, such as specifications for the salinity of treated wastewater. The latter may be strictly enforced in the case of, e.g., wastewater reuse in agriculture. The degradation of ibuprofen could be achieved without significant generation of toxic 4-isobutylacetophenone, which is its most concerning transformation by-product. The toxic by-product had in fact low formation yields from ibuprofen in the ZVI-Fenton process, and its stability under oxidative conditions was comparable to (or even lower than) that of the parent compound. It was also relatively easy to find reaction conditions in which the degradation of ibuprofen took place without important release of dissolved Fe from ZVI: this is potentially important because, if the dissolved Fe concentration is within acceptable limits, there is no need of an iron precipitation step after the ZVI-Fenton process.

To achieve the ZVI-Fenton degradation of ibuprofen in secondary wastewater, the decrease in degradation efficiency caused by interfering agents (organic compounds and inorganic ions) was compensated for by carrying out multiple $\mathrm{H}_{2} \mathrm{O}_{2}$ additions. The results of wastewater titration suggest how many equivalents of acid are needed to fix each $\mathrm{pH}$ value (note that the same equivalents of base are required to restore the initial $\mathrm{pH}$ after treatment). A noticeable result is that the equivalents of acid used to reach $\mathrm{pH} 5$ were not much different from those required to reach $\mathrm{pH}$ 4. Overall, when taking into account the degradation efficiency, the acid/base equivalents needed to fix $\mathrm{pH}$, as well as the concentration/loading of the used Fenton reagents, it is concluded that ibuprofen degradation in the studied wastewater could be carried out at either pH 4 or 6 , with cheaper operation at $\mathrm{pH} 4$. The availability of several conditions in which 
degradation is possible and potentially convenient is an advantage, because it may help meet diverse requirements of wastewater discharge or reuse in different contexts.

\section{Conflicts of interest}

There are no conflicts to declare.

\section{Acknowledgements}

DV acknowledges financial support by University of Torino and Compagnia di San Paolo (project CSTO168282-ABATEPHARM). The same source provided funding for SB's bursary. 
Avetta, P., Pensato, A., Minella, M., Malandrino, M., Maurino, V., Minero, C., Hanna, K., \& Vione, D. (2015). Activation of persulfate by irradiated magnetite: Implications for the degradation of phenol under heterogeneous photo-Fenton-like conditions. Environmental Science \& Technology, 49(2), 1043-1050.

Balabanič, D., Hermosilla, D., Merayo, N., Krivograd Klemenčič, A., \& Blanco, A. (2012). Comparison of different wastewater treatments for removal of selected endocrine-disruptors from paper mill wastewaters. Journal of Environmental Science and Health, Part A, 47(10), 1350-1363.

Bertinetti, S., Hanna, K., Minella, M., Minero, C., \& Vione, D. (2019). Fenton-type processes triggered by titanomagnetite for the degradation of phenol as model pollutant. Desal. Water Treat. $151,117-127$.

Busca, G., Berardinelli, S., Resini, C. \& Arrighi, L. (2008). Technologies for the removal of phenol from fluid streams: A short review of recent developments. Journal of Hazardous Materials, 160(2-3), 265-288.

Buxton, G. V., Greenstock, C. L., Helman, W. P., \& Ross, A. B. (1988). Critical review of rate constants for reactions of hydrated electrons, hydrogen atoms and hydroxyl radicals $\left({ }^{\circ} \mathrm{OH} /{ }^{\circ} \mathrm{O}^{-}\right)$ in aqueous solution. Journal of Physical and Chemical Reference Data, 17(2), 513-886.

Comninellis, C., Kapalka, A., Malato, S., Parsons, S. A., Poulios, I., \& Mantzavinos, D. (2008). Perspective advanced oxidation processes for water treatment: Advances and trends for R\&D. Journal of Chemical Technology \& Biotechnology, 83(6), 769-776.

Cushing, B. L., Kolesnichenko, V. L., \& O’Connor, C. J. (2004). Recent advances in the liquidphase syntheses of inorganic nanoparticles. Chemical Reviews, 104(9), 3893-3946.

De Lange, H. J., Peeters, E. T. H. M. \& Lürling, M. (2009). Changes in ventilation and locomotion of Gammarus pulex (Crustacea, Amphipoda) in response to low concentrations of pharmaceuticals. Human and Ecological Risk Assessment, 15(1), 111-120.

Fang, Y., Yin, W., Jiang, Y., Ge, H., Li, P., \& Wu, J. (2018). Depth treatment of coal-chemical engineering wastewater by a cost-effective sequential heterogeneous Fenton and biodegradation process. Environmental science and pollution research international, 25(13), 13118-13126.

Fernández-Alba, A. R., Hernando, D., Agüera, A. A., Cáceres, J., \& Malato, S. (2002). Toxicity assays: A way for evaluating AOPs efficiency. Water Research, 36(17), 4255-4262. 
Frech, H. E., \& Miller, R. D. (2004). The effects of pharmaceutical consumption and obesity on the quality of life in the organization of economic cooperation and development (OECD) countries. Pharmacoeconomics, 22(2), 25-36.

Frew, J. E., Jones, P., \& Scholes, G. (1983). Spectrophotometric determination of hydrogen peroxide and organic hydropheroxides at low concentrations in aqueous solution. Analytica Chimica Acta, $155,139-150$.

Fu, F., Dionysiou, D. D., \& Liu, H. (2014). The use of zero-valent iron for groundwater remediation and wastewater treatment: A review. Journal of Hazardous Materials, 267, 194-205.

Gligorovski, S., Strekowski, R., Barbati, S., \& Vione, D. (2015). Environmental implications of hydroxyl radicals ( $\left.{ }^{\circ} \mathrm{OH}\right)$. Chemical Reviews, 115(24), 13051-13092.

Harimurti, S., Dutta, B. K., Ariff, I. F. B. M., Chakrabarti, S., \& Vione, D. (2010). Degradation of monoethanolamine in aqueous solution by Fenton's reagent with biological post-treatment. Water, Air, \& Soil Pollution, 211(1), 273-286.

Homem, V., \& Santos, L. (2011). Degradation and removal methods of antibiotics from aqueous matrices - A review. Journal of Environmental Management, 92(10), 2304-2347.

Huijbers, P. M., Blaak, H., De Jong, M. C., Graat, E. A., Vandenbroucke-Grauls, C. M., \& De Roda Husman, A. M. (2015). Role of the environment in the transmission of antimicrobial resistance to humans: A review. Environmental Science \& Technology, 49(20), 11993-12004.

Kanel, S. R., Greneche, J. -M., \& Choi, H. S. (2006). Arsenic (V) Removal from groundwater using nano scale zero-valent iron as a colloidal reactive barrier material. Environmental Science \& Technology, 40(6), 2045-2050.

Kumarathilaka, P., Oze, C., Indraratne, S. P., \& Vithanage, M. (2016). Perchlorate as an emerging contaminant in soil, water and food. Chemosphere, 150, 667-677.

Le, T. X. H., Nguyen, T. V., Amadou Yacouba, Z., Zoungrana, L., Avril, F., Nguyen, D. L., Petit, E., Mendret, J., Bonniol, V., Bechelany, M., Lacour, S., Lesage, G., \& Cretin, M. (2017). Correlation between degradation pathway and toxicity of acetaminophen and its by-products by using the electro-Fenton process in aqueous media. Chemosphere, 172, 1-9.

Le Corre, K. S., Ort, C., Kateley, D., Allen, B., Escher, B. I., \& Keller, J. (2012). Consumptionbased approach for assessing the contribution of hospitals towards the load of pharmaceutical residues in municipal wastewater. Environment International, 45(1), 99-111.

Le-Minh, N., Khan, S. J., Drewes, J. E., \& Stuetz, R. M. (2010). Fate of antibiotics during municipal water recycling treatment processes. Water Research, 44(15), 4295-4323.

Li, L., \& Goel, R. K. (2010). Role of hydroxyl radical during electrolytic degradation of contaminants. Journal of Hazardous Materials, 181(1-3), 521-525. 
Ling, R., Chen, J. P., Shao, J., \& Reinhard, M. (2018). Degradation of organic compounds during the corrosion of ZVI by hydrogen peroxide at neutral pH: Kinetics, mechanisms and effect of corrosion promoting and inhibiting ions. Water Research, 134, 44-53.

Litter, M. I., \& Slodowicz, M. (2017). An overview on heterogeneous Fenton and photo-Fenton reactions using zerovalent iron materials. Journal of Advanced Oxidation Technologies, 20(1), 20160164.

Lowry, G. V., \& Johnson, K. M. (2004). Congener-specific dechlorination of dissolved PCBs by microscale and nanoscale zerovalent iron in a water/methanol solution. Environmental Science \& Technology, 38(19), 5208-5216.

Méndez-Arriaga, F., Esplugas, S., \& Giménez, J. (2010). Degradation of the emerging contaminant ibuprofen in water by photo-Fenton. Water Research, 44(2), 589-595.

Minella, M., Marchetti, G., De Laurentiis, E., Malandrino, M., Maurino, V., Minero, C., Vione, D., \& Hanna, K. (2014). Photo-Fenton oxidation of phenol with magnetite as iron source. Applied Catalysis B: Environmental, 154-155, 102-109.

Minella, M., Sappa, E., Hanna, K., Barsotti, F., Maurino, V., Minero, C. \& Vione, D. (2016). Considerable Fenton and photo-Fenton reactivity of passivated zero-valent iron. RSC Advances, 6(89), 86752-86761.

Minella, M., De Bellis, N., Gallo, A., Giagnorio, M., Minero, C., Bertinetti, S., Sethi, R., Tiraferri, A., \& Vione, D. (2018). Coupling of nanofiltration and thermal Fenton reaction for the abatement of carbamazepine in wastewater. ACS Omega, 3(8), 9407-9418.

Miranda, M. A., Morera, I., Vargas, F., Gomezlechon, M. J., \& Castell, J. V. (1991). In-vitro assessment of the phototoxicity of anti-inflammatory 2-arylpropionic acids. Toxicology in Vitro, $5(5-6), 451-455$.

Mirzaei, A., Chen, Z., Haghighat, F., \& Yerushalmi, L. (2017). Removal of pharmaceuticals from water by homo/heterogeneous Fenton-type processes - A review. Chemosphere, 174, 665-688.

Neyens, E., \& Baeyens, J. A. (2003). A review of classic Fenton's peroxidation as an advanced oxidation technique. Journal of Hazardous Materials, 98(1-3), 33-50.

Nidheesh, P. V. (2015) Heterogeneous Fenton catalysts for the abatement of organic pollutants from aqueous solution: A review. RSC Advances, 5(51), 40552-40577.

Park, J., Cho, K. H., Lee, E., Lee, S., \& Cho, J. (2018). Sorption of pharmaceuticals to soil organic matter in a constructed wetland by electrostatic interaction. Science of The Total Environment, $635,1345-1350$.

Pasquini, L., Munoz, J. F., Pons, M. N., Yvon, J., Dauchy, X., France, X., Le, N. D., France-Lanord, C., \& Görner, T. (2014). Occurrence of eight household micropollutants in urban wastewater 
and their fate in a wastewater treatment plant. Statistical evaluation. Science of The Total Environment, 481, 459-468

Pastrana-Martínez, L. M., Pereira, N., Lima, R., Faria, J. L., Gomes, H. T., \& Silva, A. M. T. (2015). Degradation of diphenhydramine by photo-Fenton using magnetically recoverable iron oxide nanoparticles as catalyst. Chemical Engineering Journal, 261, 45-52.

Pignatello, J. J., Oliveros, E., \& MacKay, A. (2006). Advanced oxidation processes for organic contaminant destruction based on the Fenton reaction and related chemistry. Critical Reviews in Environmental Science and Technology, 36(1), 1-84.

Rezaei, F., \& Vione, D. (2018). Effect of $\mathrm{pH}$ on zero valent iron performance in heterogeneous Fenton and Fenton-like processes: A review. Molecules 23, article \#3127.

Richardson, M. L., \& Bowron, J. M. (1985). The fate of pharmaceutical chemicals in the aquatic environment. Journal of Pharmacy and Pharmacology 37(1), 1-12.

Richardson, S. D., \& Ternes, T. A. (2014). Water analysis: emerging contaminants and current issues. Analytical Chemistry, 86(6), 2813-2848.

Rubasinghege, G., Gurung, R., Rijal, H., Maldonado-Torres, S., Chan, A., Acharya, S., Rogelj S., \& Piyasena, M. (2018). Abiotic degradation and environmental toxicity of ibuprofen: Roles of mineral particles and solar radiation. Water Research, 2018, 131, 22-32.

Ruggeri, G., Ghigo, G., Maurino, V., Minero, C., \& Vione, D. (2013). Photochemical transformation of ibuprofen into harmful 4-isobutylacetophenone: Pathways, kinetics, and significance for surface waters. Water Research, 47(16), 6109-6121.

Saeid, S., Tolvanen, P., Kumar, N., Eränen, K., Peltonen, J., Peurla, M., Mikkola, J. P., Franz, A. \& Salmi, T. (2018). Advanced oxidation process for the removal of ibuprofen from aqueous solution: A non-catalytic and catalytic ozonation study in a semi-batch reactor. Applied Catalysis B: Environmental, 230, 77-90.

Sandell, E. B. (1950). Colorimetric Determination of Traces of Metals. vol. 3, $2^{\text {nd }}$ edn. New York: Interscience Publishers, 688 pp.

Stasinakis, A. S., Mermigka, S., Samaras, V. G., Farmaki, E., \& Thomaidis, N. S. (2012). Occurrence of endocrine disrupters and selected pharmaceuticals in Aisonas River (Greece) and environmental risk assessment using hazard indexes. Environmental science and pollution research international, 19(5), 1574-1583.

Tang, S. C. N., \& Lo, I. M. C. (2013). Magnetic nanoparticles: Essential factors for sustainable environmental applications. Water Research, 47(8), 2613-2632. 
Usman, M., Byrne, J. M., Chaudhary, A., Orsetti, S., Hanna, K., Ruby, C., Kappler, A., \& Haderlein, S. B. (2018). Magnetite and green rust: Synthesis, properties, and environmental applications of mixed-valent iron minerals. Chemical Reviews, 118(7), 3251-3304.

Van Boeckel, T. P., Gandra, S., Ashok, A., Caudron, Q., Grenfell, B. T., Levin, S. A., \& Laxminarayan, R. (2014). Global antibiotic consumption 2000 to 2010: An analysis of national pharmaceutical sales data. The Lancet Infectious Diseases, 14(8), 742-750.

Vione, D., Maddigapu, P. R., De Laurentiis, E., Minella, M., Pazzi, M., Maurino, V., Minero, C., Kouras, S., \& Richard, C. (2011). Modelling the photochemical fate of ibuprofen in surface waters. Water Research, 45(20), 6725-6736.

Wang, X. H, \& Lin, A. Y. C. (2012). Phototransformation of cephalosporin antibiotics in an aqueous environment results in higher toxicity. Environmental Science \& Technology, 46(22), 1241712426.

Watts, R. J., Washington, D., Howsawkeng, J., Loge, F. J., \& Teel, A. L. (2003). Comparative toxicity of hydrogen peroxide, hydroxyl radicals, and superoxide anion to Escherichia Coli. Advances in Environmental Research, 7(4), 961-968.

Wu, W., Yin, S., Liu, H., Niu, Y., \& Bao, Z. (2014). The geostatistic-based spatial distribution variations of soil salts under long-term wastewater irrigation. Environmental Monitoring and Assessment, 186(10), 6747-6756.

Zhang, X., Oakes, K. D., Ciu, S. F., Bragg, L., Servos, M. R., \& Pawliszyn, J. (2010). Tissuespecific in vivo bioconcentration of pharmaceuticals in rainbow trout (Oncorhynchus mykiss) using space-resolved solid-phase microextraction. Environmental Science \& Technology, 44(9), 3417-3422.

Zhong, Y., Liang, X., Zhong, Y., Zhu, J., Zhu, S., Yuan, P., He, \& Zhang, J. (2012). Heterogeneous UV/Fenton degradation of TBBPA catalyzed by titanomagnetite: Catalyst characterization, performance and degradation products. Water Research, 46(15), 4633-4644.

Zorita, S., Martensson, L., Mathiasson, L. (2009). Occurrence and removal of pharmaceuticals in a municipal sewage treatment system in the south of Sweden. Science of The Total Environment, 407(8), 2760-2770. 


\section{Author contributions}

Marco Minella contributed to the planning of the work, revised the draft manuscript and edited the manuscript in the last version, Stefano Bertinetti carried out the degradation experiments, Khalil Hanna synthesized the materials investigated in the work, Claudio Minero revised the draft and Davide Vione conceptualized the work and wrote the draft manuscript. 
- ZVI (Zero-Valent Iron)-Fenton was effective in the degradation of ibuprofen

- Degradation was most efficient at pH 3, and efficiency decreased at higher $\mathrm{pH}$

- Ibuprofen could still be degraded at $\mathrm{pH}$ 6, by increasing the $\mathrm{ZVI}$ or $\mathrm{H}_{2} \mathrm{O}_{2}$ dose

- Multiple $\mathrm{H}_{2} \mathrm{O}_{2}$ additions allowed for ibuprofen degradation in secondary wastewater

- Treatment costs are quite competitive, in the range of 0.06-0.10 $\$ \mathrm{~m}^{-3}$ 